\title{
豊後水道近傍で発生した歴史的被害地震の地震規模
}

\author{
鹿島建設株式会社・小堀研究室* 神田克久・武村雅之 \\ 四国電力株式会社** 高 橋 利 昌 ・浅野彰洋・大内泰 志・川崎真治 \\ 奈良県在住*** 宇佐美龍夫
}

\section{Magnitudes of Major Historical Earthquakes in the Vicinity of the Bungo Channel}

\author{
Katsuhisa Kanda and Masayuki TaKemURA \\ Kobori Research Complex, Kajima Corporation, KI Building, Akasaka 6-5-30, \\ Minato-ku, Tokyo 107-8502, Japan
}

Toshimasa Takahashi, Akihiro Asano, Taishi Oouchi, and Shinji KawASAKI

Geological \& Earthquake Engineering Group, Civil \& Architectural Engineering Dept., Shikoku Electric Power Co., Inc., 2-5 Marunouchi, Takamatsu 760-8573, Japan

\section{Tatsuo Usami}

Nissei Eden-no-sono 6411, Takatsukadai 1-6-1, Kawai-cho, Kitakatsuragi-gun, Nara 636-0071, Japan

(Received May 24, 2007; Accepted December 6, 2007)

The major intraslab earthquakes have recurrently occurred in the subducting slab of the Philippine Sea plate in the vicinity of the Bungo Channel and caused great damage. Since the intraslab earthquakes tend to generate more short period seismic waves compared to plate boundary and shallow crustal earthquakes, seismic magnitude of historical earthquakes should be carefully estimated from seismic intensity data. We found that the 1596/9/4, 1749/5/25, 1854/12/26, and 1968/8/6 earthquakes fall under major events in this region. These earthquakes except the 1596 event were identified as intra-slab events. The 1596 event was inferred as a shallow crustal earthquake occurring at a fault in Beppu Bay from the tsunami record and geological survey. At first, the seismic intensity data of the 1596, 1749, and 1854 earthquakes estimated from damage records written in old documents were digitized to analyze their source characteristics. The seismic intensity data were modified using a site correction factor obtained from a difference of observed intensity from estimated intensity with the attenuation relationship of recent earthquakes. The inversion analysis using seismic intensity data was carried out to evaluate short-period wave radiation zones on a given fault plane. It showed that the location of centroid of short-period wave radiation zone was near the corresponding epicenter [Usami (2003)] except the 1749 event. We could also obtain an optimum magnitude $M_{I}$ that gives the minimum estimation error. It was indicated that the 1596 earthquake was inferred as a shallow crustal event $\left(M_{I}=7.2\right)$ near the center of Beppu Bay, the 1749 earthquake $\left(M_{I}=6.6\right)$ quite resembled the 1968 event in short-period wave radiation zone and magnitude, and the 1854 earthquake $\left(M_{I}=7.0\right)$ was the largest event among historical intra-slab earthquakes in this region. Based on the magnitude revaluation, the empirical equation of relationship between magni-

\footnotetext{
* ₹107-8502 東京都港区赤坂 6-5-30 KI ビル

** $\mathbf{7} 760-8573$ 高松市丸の内 $2-5$
}

*** $\mathbf{T} 636-0071$ 奈良県北葛城郡河合町高塚台 1-81 ニッセイエデンの園 64 
tude and isoseismal area of $I_{\mathrm{JMA}} \geqq 5$ was modified to estimate magnitude of intra-slab earthquakes in the Bungo Channel adequately.

Key words: Intraslab earthquake, Historical earthquake, Seismic intensity, Inversion analysis, Magnitude

\section{§1.はじめに}

愛媛県と大分県に挟まれる伊予灘から豊後水道の下で は，海洋プレート内部のいわゆるスラブ内地震が頻繁に 発生している，松崎・他 (2003) によると，この地域で は，フィリピン海プレート上面は九州側に向かって傾斜 し, 曲げフロントと呼ばれる豊後水道の中央を通る南北 ラインを境に傾斜角が 5 ～ $8^{\circ}$ から約 $35^{\circ}$ に急激に折れ曲 がる，曲げフロントを挟んで四国側では，南北に圧縮力 が働いて横ずれ断層が卓越し, 九州側ではフィリピン海 プレートの曲げによる東西方向の引張力が働いて正断層 型が卓越する. 四国側の南北の圧縮力はプレートの沈み 込みによると考えられるが, 九州側の引張力の原因とし ては, 佃・三浦 (2002) はプレートの自重だけでなく九 州での火山などの上昇するマントル対流活動による力が 原因ではないかと指摘している，曲げフロントが交差す る佐田岬半島の付根付近は応力場の遷移部で, ここで発 生する地震は両方の特性が現れ, 最む地震活動度が高 い.

近年では, 1968 年 8 月 6 日に気象庁マグニチュード $M_{J}=6.6$ の地震が佐田岬半島付根の南側で発生し, 愛媛 県を中心に被害が発生した [宇佐美 (2003)].この地震 については, Shiono and Mikumo (1975) によって, 観 測記録の分析に基づいて, フィリピン海プレートの上面 から内部に西北西に傾斜角 $70^{\circ}$ 程度で傾く断層面で, 左 横ずれ成分を含む正断層型の地震であることが明らかに されている.

また, 佐田岬半島の北側には中央構造線断層帯の西端 のセグメントがある。中央構造線断層帯の主な動きは右 横ずれであり, 四国中〜東部は $7 \mathrm{~m} /$ 千年程度の平均変 位速度をむつが，この地域はその数分の 1 以下で, 活動 度は低い [岡田 (2006)]。この中央構造線を九州側に延 長した領域には大分県東部の豊予海峡付近から, 別府湾 内, 大分平野を経て熊本県境付近まで, ほぼ東西方向に 分布する別府一万年山断層帯がある。この一番東部の別 府湾付近には，主として断層の北側が相対的に隆起する 正断層の別府湾一日出生断層帯がある. 平均的な上下方 向の変位速度は, $3 \mathrm{~m} /$ 千年程度もしくはそれ以上で あった可能性がある [地震調查研究推進本部 (2005)]. 大分県付近の内陸地殼内の歴史地震は, スラブ内地震に 比べて記録が極めて少ない，最近の近傍の内陸地殼内の 被害地震としては, 1975 年 4 月 21 日大分県中部の地
震 $\left(M_{J} 6.4\right)$ が発生している．この地震は対象としている 海域から南西方向に離れた陸域にあり, 別府一万年山断 層帯と屯関係のない地震と考えられる。この地震の被害 では, 死者こそ出なかったものの, 負傷者が 22 人, 全壊 家屋が 58 棟に達し, 山下池湖畔のホテルが大破した.

歴史地震の規模を決める方法としては, 被害記録から 推定した震度デー夕を用いてある特定の震度（例えば震 度 4, 5, 6) 以上の領域面積之地震規模 $M$ との経験的な 関係 [例えば，村松 (1969), 勝又・徳永 (1971)］を用い るのが一般的である. また, 類似の地震の規模が既知で あれば震度の領域面積の関係を分析して補正を行う [中 村・笠原 (2001)]。さらに，プレート境界地震であれば 津波の波源域の面積と地震規模の関係 [Hatori (1969)] や津波の波高之震源距離から評価される羽鳥の津波マグ ニチュードと地震規模の関係 [羽鳥 (1995)] を用い, 内 陸地殼内地震であれば断層長さと地震規模の関係式およ び断層面の変位と地震規模の関係式 [松田 (1995)] など を用いて地震学的な判断を加えて求める [宇佐美 (2003)]. その際, 被害地震の多くを占める震源が浅い地 震に関する経験は豊富にあるが，スラブ内地震に対する 経験は一般に少ないことに注意が必要になる。 その他, 断層モデルから波形合成を行い, 計測震度を計算して歴 史地震の震度と比較する手法も提案されている[例え ば, 引田・工藤 (2001)].

伊予灘から豊後水道近傍で歴史地震について調べてみ ると，このようなマグニチュード 7 前後の被害地震がい くつ加発生している。 スラブ内で発生するマグニチュー ド 7 前後の大地震の場合, プレート境界地震や内陸地殼 内地震に比べて短周期地震波の励起が大きいことが知ら れて抢り [池田・他 (2003)], 歴史地震についてもスラ ブ内地震のこの特性を正しく考慮して地震規模を評価す る必要がある. また, 内陸地殼内地震については, 震源 が浅いことによるスラブ内地震と異なった波動伝播の特 性を考慮して地震規模を評価する必要がある.

一方, 著者らは震度分布のデー夕を用いた震源の短周 期地震波の放出エネルギー分布をインバージョンする手 法を開発し [神田・他 (2003)], 気象庁の震度記録だけ でなく, 古い地震は被害記録から推定した震度を用いる ことによって, 最近の地震から歴史地震までに適用して きた。 その際, 震源域ごとに近傍の同種の地震の分析を 行い, 震度の距離減衰式抢よび地点ごとの摇れやすさを 
Table 1. List of historical major earthquakes in the vicinity of the Bungo Channel considered in the present paper. The location of hypocenter and magnitude are referred to JMA (2007) for the 1968 event and Usami (2003) for other events. Numerals in parenthesis of the focal depth are assumed as the depth in the upper surface of the seismogenic zone of the Philippine Sea plate beneath the corresponding epicenter [Matsusaki et al. (2003)]. See the listed equations and figures for the intensity attenuation relationship and relative intensity for site correction used for the present analysis.

\begin{tabular}{|c|c|c|c|c|c|c|c|c|}
\hline Date & Source location & $\begin{array}{l}\text { Long. } \\
\text { (deg.) }\end{array}$ & $\begin{array}{l}\text { Lat. } \\
\text { (deg.) }\end{array}$ & $M$ & $\begin{array}{l}\text { Focal } \\
\text { depth } \\
(\mathrm{km})\end{array}$ & Type & $\begin{array}{l}\text { Intensity } \\
\text { attenuation } \\
\text { formula }\end{array}$ & $\begin{array}{c}\text { Relative } \\
\text { intensity for } \\
\text { site correction }\end{array}$ \\
\hline $1596 / 9 / 1$ & Beppu Bay & 131.6 & 33.3 & 7.0 & 9 & $\begin{array}{c}\text { Shallow } \\
\text { crust }\end{array}$ & Eq. (5) & Fig. 8 \\
\hline $1749 / 5 / 25$ & Uwa Sea & 132.6 & 33.2 & 6.75 & (33) & \multirow{3}{*}{ Intraslab } & \multirow{3}{*}{ Eq. (4) } & \multirow{3}{*}{ Fig. 4} \\
\hline $1854 / 12 / 26$ & Bungo Channel & 132.0 & 33.25 & 7.4 & $(50)$ & & & \\
\hline $1968 / 8 / 6$ & Uwa Sea & 132.38 & 33.30 & 6.6 & 40 & & & \\
\hline
\end{tabular}

評価し，震源特性，波動伝播特性および地盤増幅特性を 考慮する. この震度インバージョン解析では, 最小 2 乗 法を用いて震度評価誤差が最小になるように断層面の短 周期地震波の発生域を推定する。 その際, 最適な地震規 模を同定することができる.

今までに, 十勝沖 [神田・武村 (2006)], 青森県東方沖 [武村・他 (2006)], 宮城県沖 [神田・武村 (2005), 武 村・神田 (2006)], 南関東 [神田・武村 (2007)], 東海・ 東南海・南海 [神田・他 (2004)] のプレート境界で繰り 返して発生する大地震に適用し, 断層面上の短周期地震 波の発生中心を求め, 同じ場所から繰り返し短周期地震 波が発生している場合とそうでない場合があることや， 波形インバージョン解析から求められたすべりの大きい 部分であるアスペリティの破壊の終端部の近傍に発生中 心がある場合があることなどを明らかにしてきた。

本論文では, 豊後水道およびその近傍の地域で発生し た M 7 クラスの歴史地震について, 点震源による距離 減衰式を用いた方法抢よび震度インバージョンによる方 法を用いて地震規模を推定する. 地震規模の基準とする 最近の地震として，スラブ内地震では 1968 年 8 月 6 日 豊後水道の地震, 内陸地殼内地震では 1975 年 4 月 21 日大分県中部地震をそれぞれ用いる.

\section{§2. 対象とする地震とそのタイプ}

解析の対象とする地震の諸元を Table 1 に示す. な お, 表中および以下の本文中の歴史地震の日付はすべて グレゴリオ暦で示す。ここでは, 豊後水道近傍で被害を 発生させた $M 7$ クラスの地震と考えられる 4 地震を選 定した，選定した地震の震度分布を Fig. 1 に示す。 ×が 震央 [宇佐美 (2003)］で, 実線で囲んだ領域が震度 5 以
上の範囲である.すでに述べた 1968 年 8 月 6 日以外の 地震について，その特徵を以下に分析する.

1596 年 9 月 1 日の豊後地震については, かなり大き な津波の発生記録があること［羽鳥 (1985)] や，別府湾 内大分市の北にあった瓜生島が海に陥没し 708 人亡く なったという伝承があり [宇佐美 (2003)], 浅い地震の 可能性が高い. 別府一万年山断層帯の長期評価 [地震調査 研究推進本部 (2005)] では, 音波探査およびピストンコ アリング調査と照合し，1596 年の地震の際に別府湾-日 出生断層帯東部が活動した可能性が高いことを指摘して いる. この地震は別府湾の内陸地殻内地震として, 震源 位置や断層面を仮定して解析を行うこととする.

1596 年 9 月 1 日の史料を調べると, 地震被害の記述 は大分県の別府湾沿岸が多いが, 愛媛県にも見られる. 松山市保免の薬師寺の本堂, 仁王門が倒壊し, 西条市北 条の鶴岡八幡宮が倒壊した記録がある [宇佐美 (2003)]. 震度判定表 [宇佐美・大和探査 (1994)］に従えば，どち らの地点も Fig. 1 に示すように震度 6 の評価となる. 岡 田 (2006) は, 同年 9 月 1 日に愛媛県の中央構造線断層 帯の川上断層が最初に活動し, ついで 9 月 4 日に別府湾 内の断層帯が動いて豊後地震を引き起こしたのではない かと指摘した。ささらに, 翌日の 9 月 5 日に六甲・淡路島 や有馬一高槻断層帯が活動して慶長伏見地震が発生し, この 5 日間の間に四国全域の中央構造線断層帯とその 周辺で大きな複数の地震が連動的に活動したとしてい る.しかし, この地震の大分県の被害の史料の日付につ いては, 『新収日本地震史料 第二巻』[東京大学地震研 究所 (1982)] によると, 瓜生島の名が初めて登場する 1699 年に編纂された「豊府聞書」をはじめとして後世 に書かれた史料には 9 月 4 日（慶長元年閏七月十二日） 

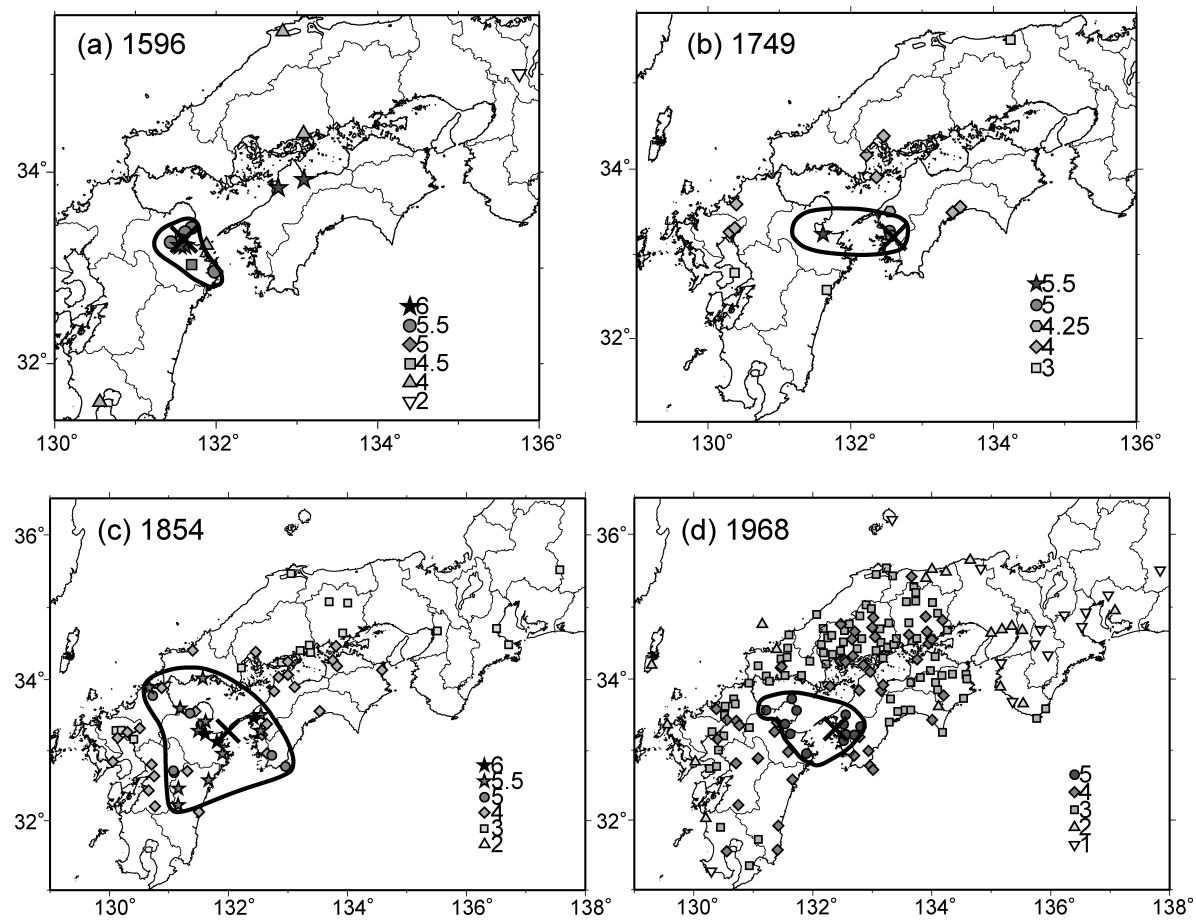

Fig. 1. Seismic intensity distribution of events around the Bungo Channel; (a) 1596/9/1, (b) 1749/5/ 25, (c) 1854/12/26, and (d) 1968/8/6. A cross indicates the epicenter for each event [Usami (2003)].

The area surrounded by a solid line shows the isoseismal area of $I_{\mathrm{JMA}} \geqq 5$.

の記述が多いが，「重祐重成伝」など直後に書かれたもの に基づいたものは 9 月 1 日（慶長元年閏七月九日）が多 い. 古文献的には, 1596 年 9 月 1 日に別府湾で地震が 発生したと考えた方が合理的である. 西条市鶴岡八幡宮 周辺は, 海岸に近い低地で地震により地裂・陥没が生 じ，神社・寺院・民家が倒壊・水没した，地盤が良くな いため現在む宅地として利用されていない[中西 (2002)]. 松山市保免の薬師寺は右手川に近いため堆積 層が厚いと考えられる，地盤条件によってどちらの地点 あ被害が大きくなった可能性がある。しかし, 石辺・島 崎 (2005) は，津波の解析に基づいて津波の波高の高さ を説明するために別府湾内の断層だけでなく, 佐賀関沖 海域の中央構造線断層帯のセグメントの連動の可能性ま では指摘しているが, 松山市近傍のセグメントまでの連 動を考えると津波の波高が高くなり過ぎると考えられ る. 中西 (2002) は, 1596 年 9 月 1 日に豊後と伊予で二 つの地震が発生した可能性を示唆しており, 西条市と松 山市の 2 地点以外の愛媛県やその周辺の地点の大きな 被害の記録が残っていないことを考え合わせると, 別府 湾から愛媛県北部の中央構造線断層帯まで連動するほど の地震ではなかったと考えられる。ここでは, 豊後と伊 予で二つの地震が発生した立場をとり, 以後の検討には
愛媛県の震度デー夕は除いて検討することとする。な 押, 1596 年の地震の他に大分県の浅い歴史地震として は, 1703 年 12 月 31 日に $M=6.5$ の地震があり, 潰家 853 などの被害地震の記録がある [宇佐美 (2003)] が, 1596 年の地震に比べ規模は小さく, 震度デー夕が不十 分なためここでは解析対象から除く。

1749 年 5 月 25 日の伊予宇和島の地震は, 1968 年 8 月 6 日豊後水道の地震 (以後, 1968 年の地震と呼ぶ) と 震度分布がよく似ている. 愛媛県の宇和島市や大洲市だ けでなく大分市で被害の記録がある [宇佐美 (2003)].

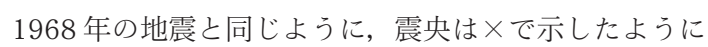
愛媛県沿岸にあり [宇佐美 (2003)], 震度 5 の範囲の東 端に位置している. 地震規模む $M=6.75$ で 1968 年の地 震とほぼ同じと考えられている. 1968 年の地震と同じ タイプのスラブ内地震として解析を行うこととする.

1854 年 12 月 26 日の伊予西部の地震は, 安政南海地 震の 2 日後に発生した規模の大きな地震である.この地 震で愛媛県の大洲市や宇和島市吉田, 大分県の大分市鶴 崎などで大きな被害をもたらし，愛媛県や九州地方では 12 月 24 日の安政南海地震よりも摇れの大きい地域が あった [宇佐美 (2003)]. Fig. 1 に示すように震度 5 以 上の範囲は解析対象とした地震の中で一番広く, この地 


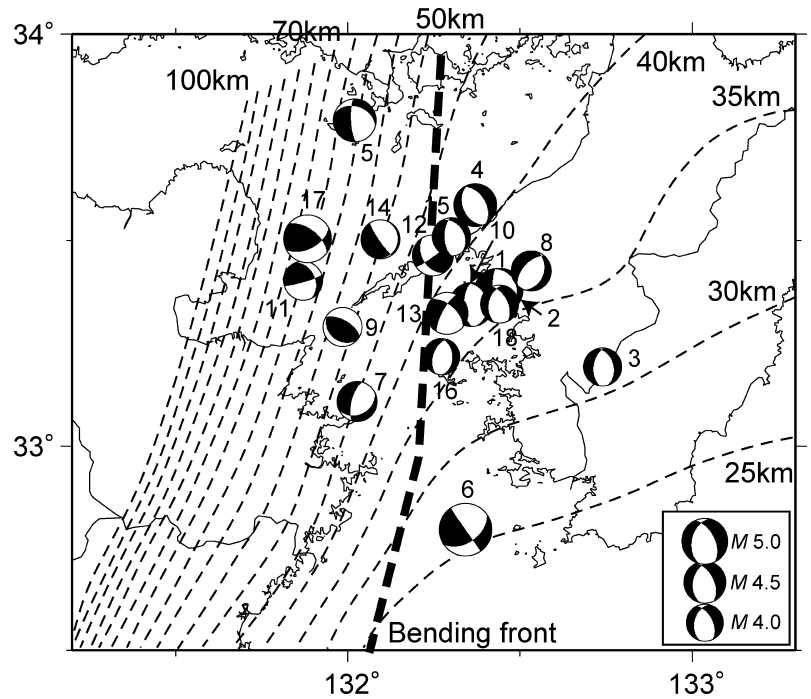

\begin{tabular}{r|r|r|c|c|c|c|c|c}
\hline No & year & date & $\begin{array}{c}\text { longitude } \\
\text { (deg.) }\end{array}$ & $\begin{array}{l}\text { latitude } \\
\text { (deg.) }\end{array}$ & $M_{J}$ & $\begin{array}{c}\text { Depth } \\
(\mathrm{km})\end{array}$ & $\begin{array}{c}\text { Number } \\
\text { of } \\
\text { intensity } \\
\text { data }\end{array}$ & $\begin{array}{c}\text { Maximum } \\
\text { hypocenter } \\
\text { distance } \\
(\mathrm{km})\end{array}$ \\
\hline 1 & 1997 & 401 & 132.44 & 33.38 & 4.7 & 52 & 40 & 162 \\
\hline 2 & 1997 & 403 & 132.43 & 33.38 & 5.0 & 52 & 156 & 256 \\
\hline 3 & 1998 & 1110 & 132.74 & 33.19 & 4.0 & 39 & 39 & 107 \\
\hline 4 & 2001 & 109 & 132.36 & 33.59 & 4.7 & 46 & 254 & 257 \\
\hline 5 & 2001 & 403 & 132.02 & 33.79 & 4.6 & 64 & 237 & 234 \\
\hline 6 & 2001 & 425 & 132.34 & 32.80 & 5.8 & 39 & 456 & 256 \\
\hline 7 & 2001 & 906 & 132.03 & 33.09 & 4.3 & 49 & 102 & 188 \\
\hline 8 & 2002 & 406 & 132.53 & 33.43 & 4.4 & 42 & 162 & 207 \\
\hline 9 & 2002 & 506 & 131.98 & 33.29 & 4.2 & 58 & 70 & 148 \\
\hline 10 & 2002 & 1013 & 132.36 & 33.35 & 4.9 & 43 & 354 & 264 \\
\hline 11 & 2003 & 531 & 131.87 & 33.40 & 4.5 & 65 & 121 & 269 \\
\hline 12 & 2004 & 420 & 132.25 & 33.47 & 4.6 & 48 & 102 & 203 \\
\hline 13 & 2005 & 525 & 132.29 & 33.32 & 4.6 & 54 & 230 & 208 \\
\hline 14 & 2005 & 904 & 132.10 & 33.50 & 4.3 & 54 & 184 & 243 \\
\hline 15 & 2006 & 201 & 132.30 & 33.51 & 4.3 & 46 & 194 & 227 \\
\hline 16 & 2006 & 422 & 132.27 & 33.22 & 4.0 & 40 & 62 & 124 \\
\hline 17 & 2006 & 926 & 131.88 & 33.51 & 5.3 & 70 & 815 & 492 \\
\hline 18 & 2006 & 1119 & 132.44 & 33.35 & 4.2 & 41 & 110 & 134 \\
\hline
\end{tabular}

Fig. 2. Intra-slab earthquakes in 1997-2006 adopted for the evaluation of empirical intensity attenuation relationship and relative intensity for site correction. Their fault mechanisms are depicted at the epicenter on the left map and their parameters are listed on the right table. The events whose magnitude is greater than 4.0 in JMA scale, recorded intensity is larger than 3 in JMA scale and focal depth is less than $70 \mathrm{~km}$ are selected. Numbers shown in the map correspond to event numbers in the first column of the right table. The depth contour of upper surface of the seismogenic zone and the bending front estimated by Matsusaki et al. (2003) are depicted by thin and thick broken lines, respectively.

域においてこのような震度分布の地震は記録にある歴史 地震として他に例がない.この地震の震央は, 曲げフロ ント［松崎・他 (2003)］の西側に位置し，スラブ内地震 の発生頻度が高く，深部低周波微動の発生域より北側の フィリピン海プレートが深くなる場所で，2003 年 9 月 〜 10月のスロースリップイベントの推定断層面付近 [小原・廣瀬 (2004)］にある.この領域は，プレート境界 の大地震が発生しない場所と考えられ，豊後水道で発生 する平均的なスラブ内地震と仮定して以後の分析を行う こととする.

\section{§3. 距離減衰式と相対震度}

\section{1 スラブ内地震 (1749 年, 1854 年および 1968 年 の地震)}

スラブ内地震と考えられる 1749 年, 1854 年および 1968 年の地震の分析に用いる距離減衰式と地点ごとの 摇れやすさを表す震度の補正值 (以後, 相対震度と呼ぶ) を評価する．最近発生した豊後水道近傍地域のスラブ内 地震の震源执よび震度デー夕を用いて分析する. 分析に 用いる地震は, Fig. 2 に示す $M_{J} 4.0$ 以上で最大震度が震 度 3 （計測震度 2.5）以上の 1997〜2006 年の 18 地震 [気象庁 $(2006,2007)$ ～とする. 1968 年豊後水道の地震 を含めて 1996 年以前の地震は，震度観測点が少ないこ
とと整数值の震度データしかないため精度上問題がある ため用いていない，また，それぞれの地震の震源深さは 地震発生層上面より深く, 38〜 $70 \mathrm{~km}$ の範囲にあり, 九 州寄りの深さ $70 \mathrm{~km}$ を超える地震は, 震度が瀬戸内海 方面に大きく，九州側で小さくなる異常震域を示すため 除いた. 震源メカニズムとしては, Fig. 2 の太点線で示 す曲げフロントの東側では東西方向に引張軸のある正断 層の地震が多い.

次に, 評価方法について述べる. 震度 $I$ の距離減衰式 は (1) 式として定義し，Fig. 2 に示したすべての地震の 震度データを用いて回帰分析によって回帰パラメータ $a, b, c$ を評価する.

$$
I=-a \log (X)+b M_{J}+c
$$

ここで，Xは震源距離である。すべてのパラメータを一 度に回帰しても，波動伝播経路や地盤増幅など震源距離 $X$ および地震規模 $M_{J}$ 以外の影響によるばらつきが大き く, 精度よく求まらない. そこで, まず距離の対数に関 する傾きを表す $a$ については, $\log (X)$ に対する震度，お よび震度に対する $\log (X)$ の 2 通りの回帰直線を求め, その幾何平均の傾斜として求めた。 次に, $a$ を採用した 值に固定して，気象庁マグニチュード $M_{J}$ に対する $\mathrm{E}[I+a \log (X)]$, および $\mathrm{E}[I+a \log (X)]$ に対する $M_{J}$ の回 帰曲線を求めて幾何平均の傾斜として $b$ を求め, 最後に 

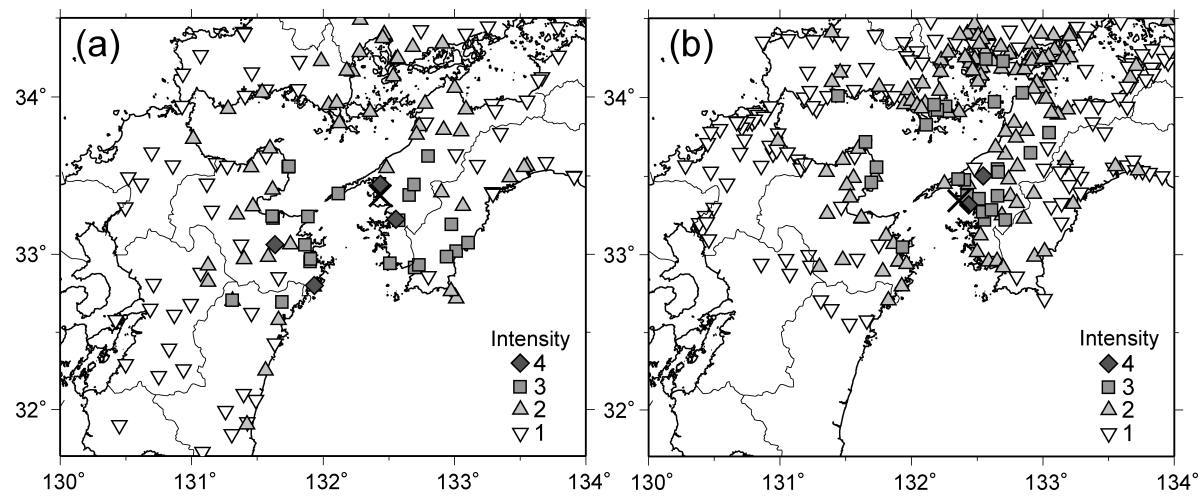

Fig. 3. Seismic intensity distribution; (a) the $1997 / 4 / 3$ event $\left(M_{J} 5.0\right)$ and (b) the $2002 / 10 / 13$ event $\left(M_{J}\right.$

4.9). A cross shows its epicenter.
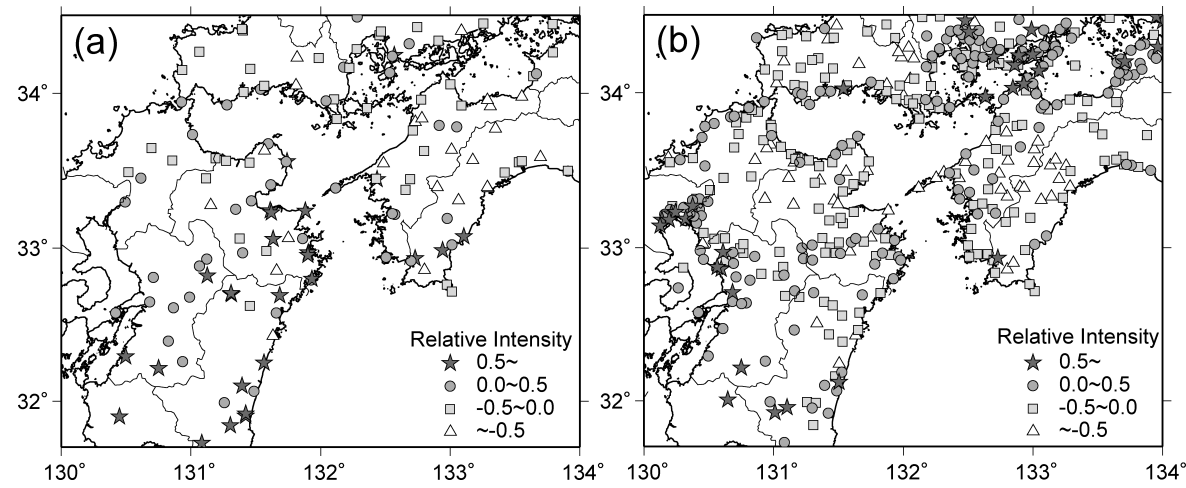

Fig. 4. Relative intensity distribution for site correction; (a) the 1997/4/3 event and (b) average of the other intra-slab events shown in Fig. 2.

残差の平均である $c$ を求めた $(\mathrm{E}[\cdot]$ は地震ごとの平均值 を示す). 最終的に距離減衰式は，(2) 式となった。(2) 式 に対する回帰分析に用いた震度デー夕の誤差の RMS 值 は 0.539 である.

$$
I=-4.2 \log (X)+1.2 M_{J}+4.3
$$

次に，摇れやすさを表す相対震度を評価する. (1) 式の $c$ は地震によって多少ばらつきがあるため, (2) 式の定数 項を $c=4.3$ と固定せず, 地震ごとに観測震度との䛊差 の RMS 值が最小となるよう $c$ を設定する. 観測震度と その距離減衰式から評価される震度の差から相対震度を 求める.

Fig. 3 に規模, 震央とも似ている 1997/4/3 ( $\left.M_{J} 5.0\right)$ と 2002/10/13 $\left(M_{J} 4.9\right)$ の地震の震度分布を比較して示 す.二つの地震の震度分布は震央の東側で似ているが, 西側で異なることがわかる，すなわち，1997/4/3の地 震は, 九州側で震度が大きく九州南部まで有感範囲が広 がり, 愛媛県沿岸と大分県沿岸の震度がほぼ同程度と なっている. Fig. 2 に示した他の地震の震度分布は
2002/10/13 の地震に近い特性を示す.そこで, 1997/ 4/3 の地震および Fig. 2 に示すそれ以外の 17 地震の平 均の相対震度を評価し, それぞれ Fig. 4(a) および (b) に 示す. 地点数については, $1997 / 4 / 3$ の地震の相対震度 は 156 点, 平均相対震度は二つ以上の地震を記録した震 度観測点で評価し， 520 点である. Fig. 4(a) で示した 1997/4/3 の地震の相対震度は, Fig. 4(b) で示したそれ 以外の地震の平均相対震度に比べて, 大分県から九州南 部で大きい. $1997 / 4 / 3$ の地震は, $M_{J} 5.0$, 震源深さ 52 $\mathrm{km}$ と地震の中では比較的規模が大きく, 震源が深い. 1968 年の地震は, 震央は $1997 / 4 / 3$ の地震と極めて近 く, 震度分布は Fig. 1(d) に示すように震度 5 以上の領 域が大分県沿岸まで震央の西側に広く, 九州南部まで震 度 4 が見られる. 1968 年の地震の震度分布は 1997/4/ 3 の地震と同様な摇れやすさの特性を示している. 1749 年の地震は 1968 年の地震と震度 5 の範囲が類似してお り, 同様な地震と考えられる. 1854 年の地震について は，愛媛県に比べて大分県側の被害が明らかに大きく 
1968 年および 1749 年の地震と明らかに異なる。それ ぞれの地震に用いる相対震度については，\$4 で点震源 を用いた手法で妥当性を検討する.

次に, 1968 年の地震の地震規模を $M_{J}=6.6$ と評価で きるよう距離減衰の (2) 式を見直す。これは，スラブ内 地震の場合, $M 7$ 前後の地震の場合短周期成分の励起が 多くなるため, 中小地震で評価した式を外挿するとマグ ニチュードを過大評価する可能性があり，それを補正す るためである. そこで, 1968 年の地震に対して, 距離減 衰式の距離に関する傾き $a=4.2$ を固定して, 1968 年の 震度データと類似した震度分布を示した $1997 / 4 / 3$ の 地震の相対震度で補正した震度デー夕を用い, $\mathrm{E}[I+a$ $\log \left(X_{e q}\right)$ を計算する. 仮定する断層面としては, Shiono and Mikumo (1975)による 1968 年の地震のメカニズ ム $\left(\right.$ Dip $=72^{\circ}$, Strike $\left.=203^{\circ}\right)$ を参考に Fig. 5 に示す 20 $\times 16 \mathrm{~km}^{2}$ の長方形の断層面とした. 断層面の深さにつ いては, 点線で示す地震発生層上面 [松崎・他 (2003)] より深くなるように最浅部の北東端を $37.3 \mathrm{~km}$ とした. 等価震源距離 $X_{e q}$ は, 断層面の $i$ 番目の小断層の震度に 関係した短周期地震波の放出エネルギー $E_{I i}$ と小断層か らの距離 $X_{i, k}$ の関数である (3) 式 [Ohno et al. (1993)] で定義し,この断層面上で均質なエネルギー分布 $E_{I i}=$ 1.0 と仮定して計算する.

$$
X_{e q, k}^{-2}=\sum_{i}\left(E_{I i} / X_{i, k}^{2}\right) / \sum_{i} E_{I i}
$$

1968 年の地震の $\mathrm{E}\left[I+a \log \left(X_{e q}\right)\right]$ を通過するように拘 束条件を与えて回州し, 距離減衰式のパラメータを決め

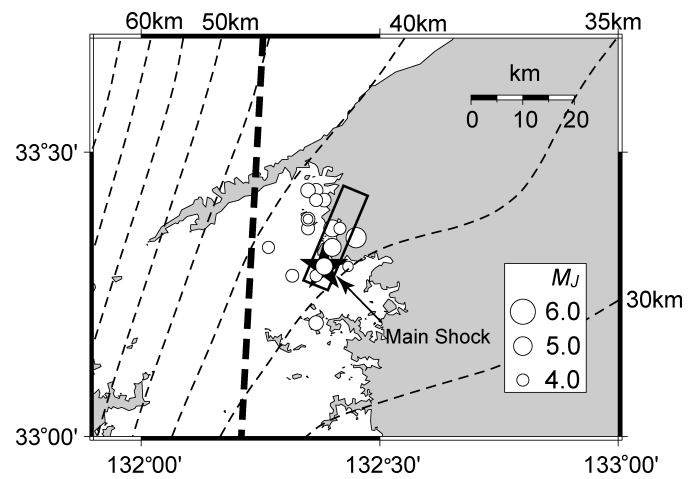

Fig. 5. Fault plane $\left(\right.$ strike $=203^{\circ}$, dip $=72^{\circ}, 20$ $\times 16 \mathrm{~km}^{2}$, depth: $35-50 \mathrm{~km}$ ) of the 1968 event from Shiono and Mikumo (1975). A black star shows the epicenter of the main shock and circles show epicenters of its aftershocks $\left(M_{J}=3.6-5.3\right) \quad$ within two months [JMA (2007)]. Broken lines show the upper surface of the seismogenic zone [Matsusaki et al. (2003)].
直して (4) 式を求めた。(4) 式に対する回帰分析に用いた 震度データの䛊差の RMS 值は 0.543 であり, (2) 式の 誤差とほとんど変わらないことが分かった。

$$
I=-4.2 \log (X)+1.33 M_{J}+3.71
$$

Fig. 6 の示す点線が (2) 式で, 実線が修正した (4) 式で ある. (4) 式は $M 4 \sim M 5$ クラスの地震では (2) 式による 評価とほとんど変わらない. 1749 年, 1854 年および 1968 年の M 7 クラスのスラブ内地震については (4) 式 を用いることとする.

\section{2 浅発地殼内地震 (1596 年の地震)}

1596 年の地震の解析に用いる距離減衰式および相対 震度については, 近年の浅い地殼内地震の分析に基づい て評価する。浅い地殼内地震に関しては, 豊後水道近傍 の地域では 1997 年以降に震度が分析できる地震はほと んど発生していない。 そこで, 西日本全域に分析対象を 広げて, まず距離減衰式については, 震度 4 以上を観測 した 2000/10/6 鳥取県西部地震および 2005/3/20 福 岡県西方沖の本震以降の震源域近傍の地震の震度デー夕 [気象庁 $(2006,2007)$ ）用いる。 なお，以下の分析に用 いる震源距離 $X$ としては, 2000/10/6 鳥取県西部地震 の本震は鷺谷・他 (2002), 2005/3/20 福岡県西方沖の 本震は Asano and Iwata (2006)のそれぞれの断層モデ ルから推定した等価震源距離とするが, 余震やその他の 地震は震源からの震源距離とする. 震央距離約 $100 \mathrm{~km}$ 以遠では Lg 波などの表面波の影響[Furumura and Kennett (2001)]が震度デー夕に表れ, 距離減衰特性が 変わるので, 震央距離 $100 \mathrm{~km}$ 以内の震度デー夕のみで

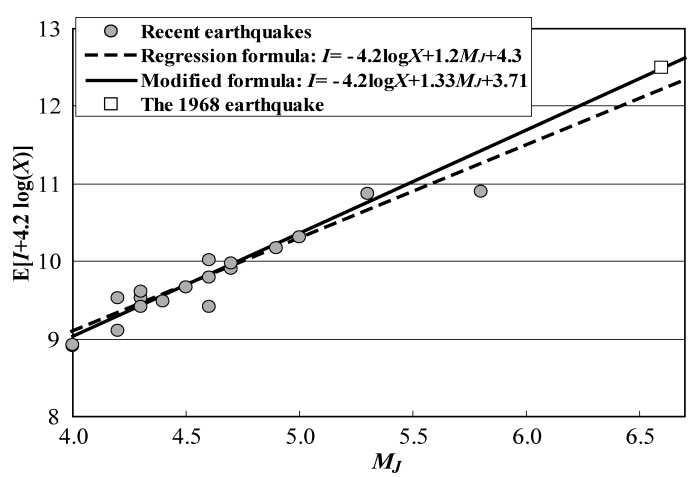

Fig. 6. Mean seismic intensity plus attenuation factor with hypocentral distance $\mathrm{E}[I+4.2$ $\log (X)]$ over magnitude $M$. A broken line shows the regression result obtained from the events in Fig. 2 depicted by gray circles. A solid line shows its modified result so as exactly to satisfy the value of the 1968 event $\left(M_{J}=6.6\right)$ depicted by an open square. 

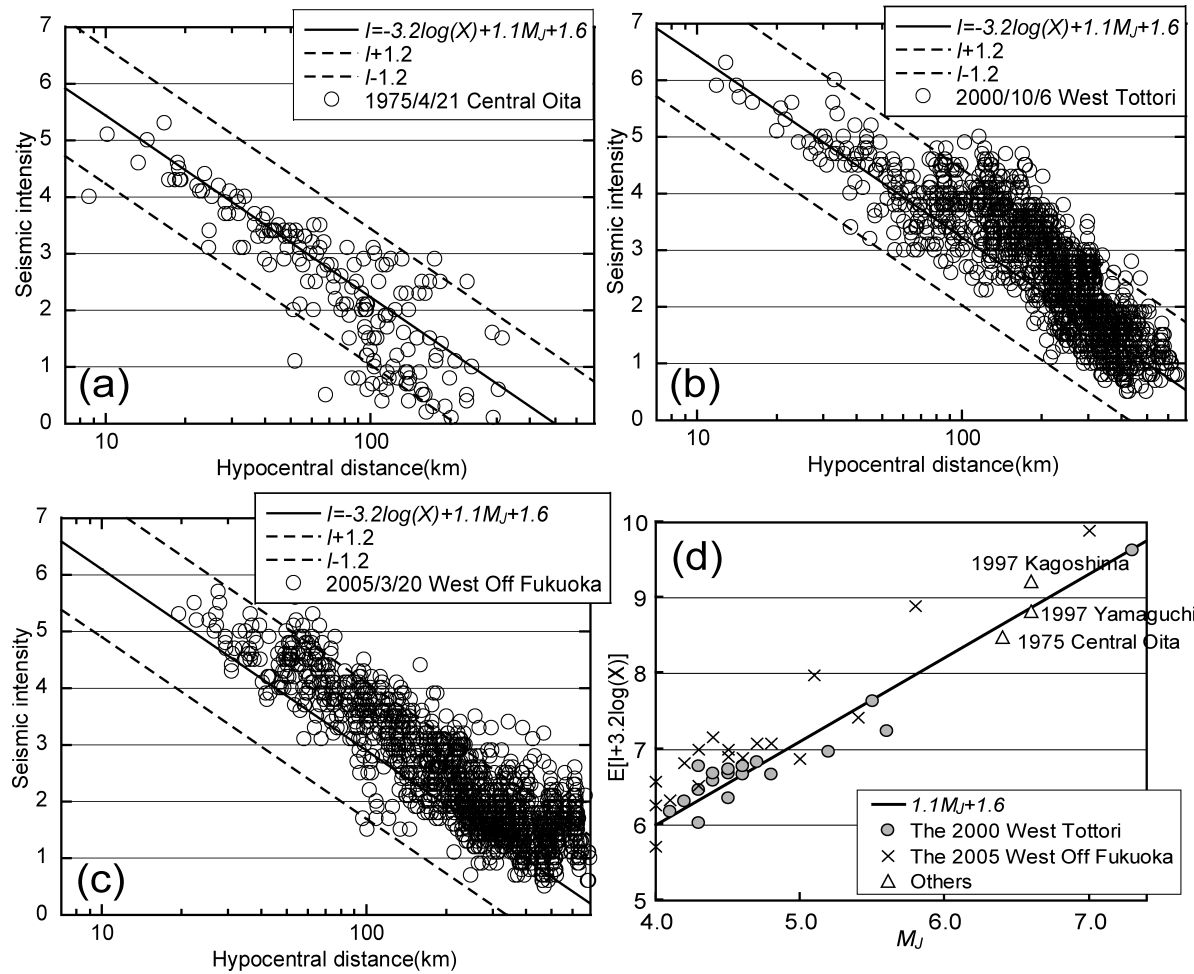

Fig. 7. Attenuation relationship of seismic intensity data of shallow crustal earthquakes; (a) the 1975 Central Oita earthquake $\left(M_{J}=6.4\right)$, (b) the 2000 West Tottori earthquake $\left(M_{J}=7.3\right)$ and (c) the 2005 West Off Fukuoka earthquake $\left(M_{J}=7.0\right)$. (d) Mean seismic intensity plus attenuation factor $\mathrm{E}[I+4.2$ $\log (X)]$ over magnitude $M$ for all the analyzed shallow crustal events.

分析を行った。スラブ内地震と同じ方法で，まず， $2000 / 10 / 6$ 鳥取県西部地震の最大震度 3.5 以上を記録 した本震㧍よび 17 余震で回帰分析を行い, 震度の距離 減衰式 (5) 式を求めた。(5) 式に対する回帰分析に用いた 震度デー夕の誤差の RMS 值は 0.572 である.

$$
I=-3.2 \log (X)+1.1 M_{J}+1.6
$$

豊後水道に比較的近い地域で発生した 1975 年大分県中 部地震では, 計測震度デー夕はないが, 地震後のアン ケート調査に基づいて市町村単位の震度分布が求められ ている [表 (1976)]. Fig. 7(a) に示すように 1975 年大分 県中部地震のアンケート震度データは震源距離の短い範 囲に扮いて実線で示す (5) 式にほぼ適合する. 点線は震 度で \pm 1.2 の範囲を示す. 1.2 は最近の地震であれば距 離減衰式の誤差の RMS 值の 2 倍強で，震度のばらつき はほぼこの点線の範囲に収まる。2000 年鳥取県西部地 震本震と 2005 年福岡県西方沖の地震本震の震度デー夕 の距離減衰について Fig. 7(b) および (c) に示す. 震源距 離 $100 \mathrm{~km}$ 以内であれば, 2000 年鳥取県西部地震本震 は (5) 式とよく適合するが, 2005 年福岡県西方沖の地震 本震の震度は (5) 式より平均で 0.6 程度大きい. 2005 年
福岡県西方沖の地震は, 短周期地震波の励起がかなり大 きかったと考えられる. 各地震の $M_{J}$ に対する $\mathrm{E}[I+3.2$ $\log (X)]$ の関係を書き加えたものを Fig. 7(d) に示す. 2000 年鳥取県西部地震本震々 2005 年福岡県西方沖の 地震本震余震以外に, Fig. 7(a) で示した 1975 年 4 月 21 日大分県中部地震, 1997 年 3 月 26 日鹿児島県薩摩 地方の地震, 1997 年 6 月 25 日山口県北部の地震を $\triangle$ で示す. 2005 年福岡県西方沖の地震だけが余震も含め て他の地震より $M$ に対する震度が大きめであることが わかる. 2005 年福岡県西方沖の地震が西日本では例外 的な地震であり，(5) 式が西日本で平均的な特性を持つ 地震に適合すると判断し, ここでは地殻内の浅い地震の 距離減衰式として (5) 式を用いることとする.

相対震度については，分析できるような地殻内の浅い 地震が豊後水道近傍でほとんど観測されていないので, スラブ内地震と同じように最近の地震の計測震度から評 価をすることができない，距離減衰式の評価に用いた地 震は震源が遠方にあるため $\mathrm{Lg}$ 波などの波動伝播の影響 が 1596 年の地震と異なるため, 相対震度の評価には適 さない. 震源が 1596 年の地震と近い地震を用いる必要 


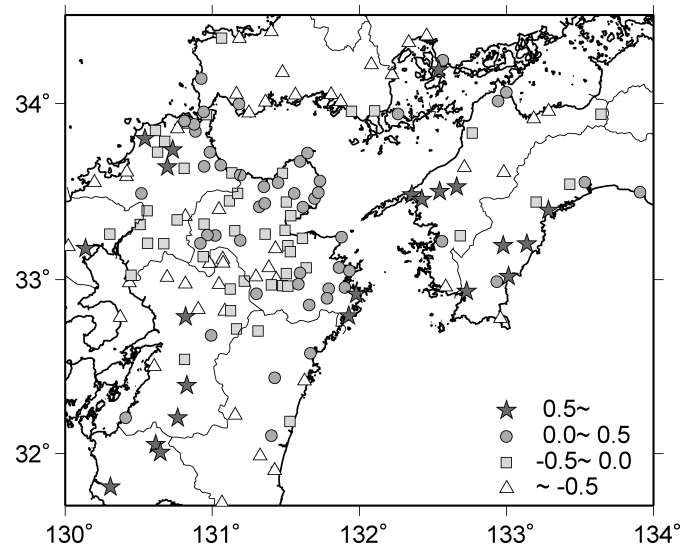

Fig. 8. Relative intensity distribution used for site correction for shallow crustal events obtained from the 1975 Central Oita earthquake.

がある. そこで, 1975 年 4 月 21 日大分県中部地震のア ンケート震度を用いて相対震度を評価する. Fig. 7(a) に 示す実線と各震度の差を相対震度とする. 得られた相対 震度の分布を Fig. 8 に示す.

各地震の以後の解析で用いる距離減衰式と相対震度に ついて, まとめて Table 1 にリストを示す.

\section{§4. 点震源による地震規模の推定}

簡便な地震規模の推定方法として, 点震源を仮定し, $\$ 3$ で評価した距離減衰式を用いて評価した震度と観測 震度の差の RMS 值が最小となる場合の地震規模を評価 する.

距離減衰式については, Table 1 に示すように, スラ ブ内地震とした 1749 年, 1854 年および 1968 年の地震 については (4) 式を用いるが, 1596 年の地震について は, 浅い地殼内地震としての (5) 式を用いて検討を行う. 震央座標 [宇佐美 (2003), 気象庁 (2006)］は, Table 1 に示すものを用いる. 震源深さは, 1968 年は気象庁 (2007) の震源データによるが, それ以外のスラブ内地震 は, Table 1 に示す震央位置における地震発生層上面 [松崎・他 (2003)］の深さとする. 1596 年の地震は震源 深さ $9 \mathrm{~km}$ と仮定した.

用いる観測震度は, 相対震度で補正しない場合と補正 する場合の両方について検討する. 相対震度について は, 1749 年, 1854 年および 1968 年のスラブ内地震は Fig. 4 に示した 2 種類の相対震度を用いて比較検討を行 う. 1596 年の地震の相対震度は, 浅い地殼内地震用の Fig. 8 に示す 1975 年の地震の相対震度を用いる. 震度 観測点の相対震度は, 平面的に線形補間して求めるが,
距離 $10 \mathrm{~km}$ 以内に相対震度の評価地点がない場合は補 正ができないと判断し，その震度デー夕を評価に用いな い. 検討に用いた震度データの条件と誤差が最小となる 場合の地震規模とその場合の誤差の RMS 值を Table 2 に示す.ここで評価した地震規模は, 震度から評価した 值なので $M_{I}$ として表示する.

スラブ内地震について相対震度の違いの影響をみる と, 最適規模 $M_{I}$ はほとんど変わらないが, 誤差の RMS 值には明らかに違いが現れている. 1749 年と 1968 年 の地震は, Fig. 4(a) に示した 1997/4/3 の地震の相対震 度を用いた方が誤差は小さい.これは，\$3 で示したよう に震度分布が類似していることと整合している。 それに 対して 1854 年の地震は, Fig. 4(b) に示した 1997/4/3 以外の地震の平均相対震度を用いた方が誤差は小さく, 他の地震と性質が異なることがわかる.

$M_{I}$ は，相対震度で補正すると 1749 年と 1854 年の地 震で 0.1 小さくなったが，他の地震は変わらない. 1968 年の地震については, 相対震度で補正する前と後の最適 な距離減衰式と観測震度の関係を Fig. 9(a) および (b) に 示す. 距離減衰式の誤差の RMS 值の 2 倍強である点線 で示した震度土 1.2 の範囲に収まり, 相対震度で補正し た方が震度值は実線で示した距離減衰式に近づき誤差が 小さくなっていることがわかる. 他の地震も誤差が小さ くなる場合が多い.

1596 年の地震については, 相対震度で補正する前と 後の最適な距離減衰式と観測震度の関係を Fig. 9(c) お よび (d) に示す. 相対震度で補正した方は, 点線で示し た最近の地震の震度の誤差の RMS 值の約 2 倍の範囲で ある距離減衰式の震度士 1.2 の範囲に収まり, 震度值は 実線で示した距離減衰式に近づき, Table 2 に示すよう に誤差が小さくなっていることがわかる. 誤差が最小と なる地震規模は $M_{I}=7.2$ となった.

相対震度で補正した場合の地震規模の最終結果を比較 すると, スラブ内地震としては 1854 年の地震が $M_{I}=$ $7.0,1749$ 年の地震が $M_{I}=6.6$ となり, 1968 年の地震と 1749 年の地震は同規模となった。距離減衰式の (4) 式の 評価で説明したように, 1968 年の地震は面震源では $M_{I}$ $=6.6$ となるように設定しているが, 点震源でも $M_{I}=$ 6.6 となることを確認した. 推定された $M_{I}$ を宇佐美 (2003) の地震規模 $M_{U}$ と比べると, 1749 年の地震は $M_{U}=6(3 / 4)$ なのでほぼ同じであるが, 1854 年の地震は $M_{U}=7.3 \sim 7.4$ より小さい值となった. 1596 年の地震に ついては $M_{U}=7.0$ より大きくなった. 


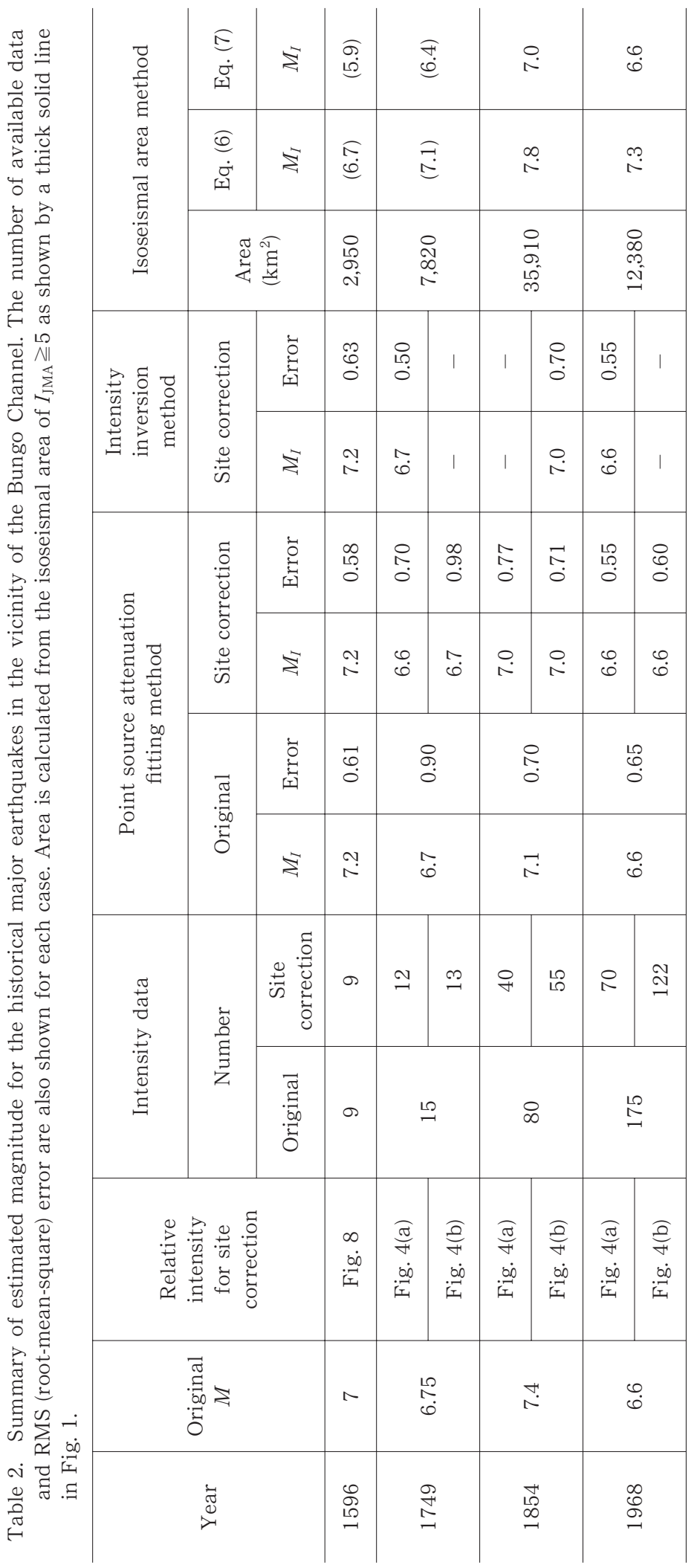



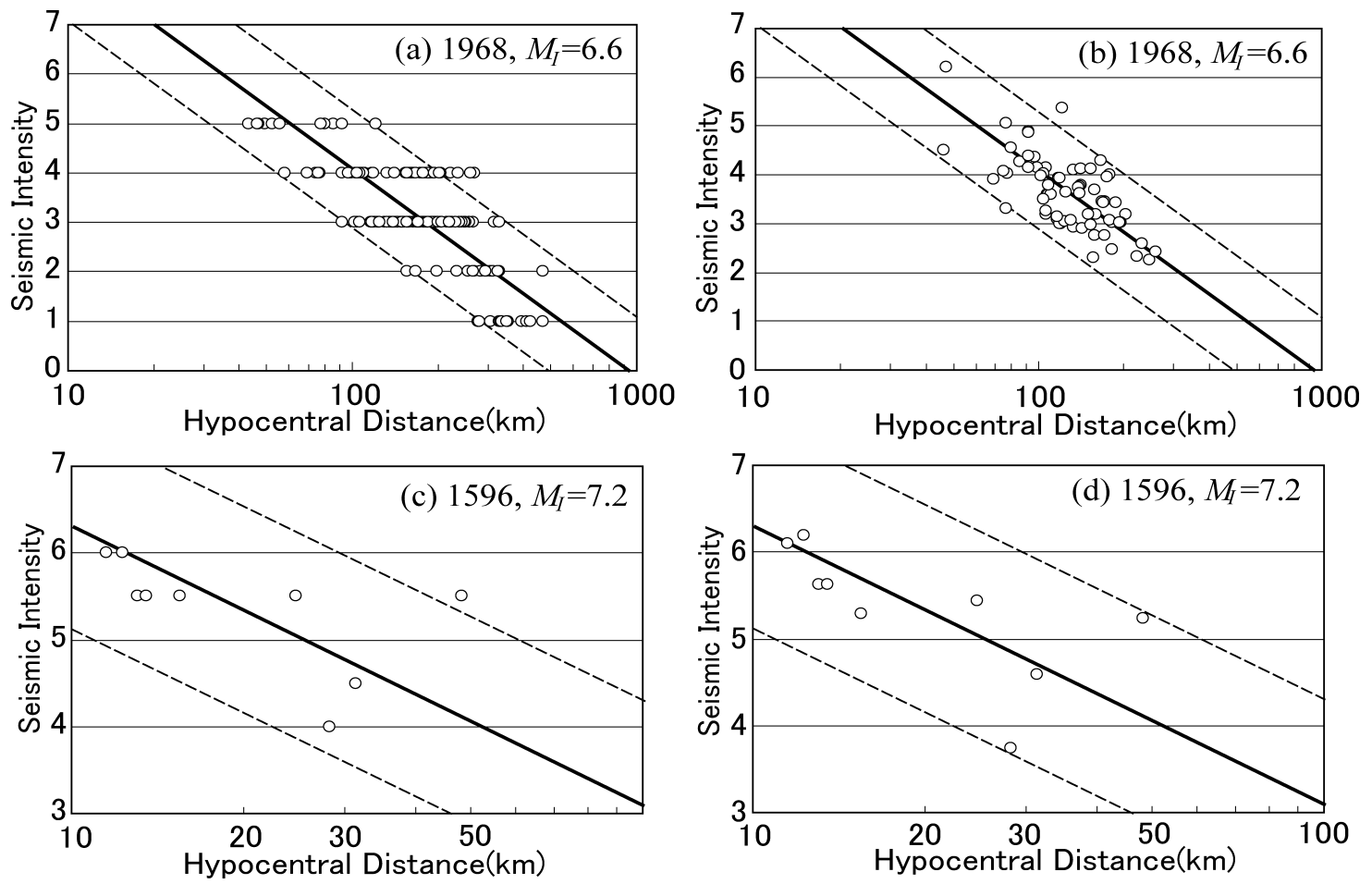

Fig. 9. Attenuation relationship for seismic intensity data over hypocentral distance for the 1968 and 1596 earthquakes; (a) Original intensity data of the 1968 event, (b) intensity data of the 1968 event corrected by relative intensity, (c) original intensity data of the 1596 event, and (d) intensity data of the 1596 event corrected by relative intensity. A solid line shows attenuation formula of equation (3). Two broken lines show the intensity bound of \pm 1.2 .

\section{§5. 震度インバージョンによる検討}

\subsection{8 年豊後水道の地震}

それぞれの地震について，神田・他 (2003) で示した 手法に従って震度インバージョン解析を行い, 誤差が最 小となる場合の短周期地震波の発生域および地震規模 $M_{I}$ を評価する.

歴史地震の前に, 1968 年の地震で震度インバージョ ン解析を行い, 短周期地震波の発生域を評価する. 地震 規模 $M_{I}$ ついては, 断層面でエネルギー分布が均質で気 象庁マグニチュード $M_{J}$ と同じ 6.6 になるように設定し ているが，この場合も $M_{I}=6.6$ になるかどうか確認す る. 1968 年の地震については, Fig. 1(d) に示した震度 分布を用いる. $\$ 3$ で等価震源距離を求めるために使っ た 1968 年の断層面と同じあのを用いる.すなわち, Shiono and Mikumo (1975) による 1968 年の地震のメ カニズム $\left(\operatorname{Dip}=72^{\circ}\right.$, Strike $\left.=203^{\circ}\right)$ を用い, $20 \times 16$ $\mathrm{km}^{2}$ の長方形の断層面を仮定し， 1 辺の長さ $4 \mathrm{~km}$ の正 方形の小断層 $5 \times 4$ 個に分割する. 断層面の最浅端（東 縁）の深さは地震発生層上面である $37.3 \mathrm{~km}$ とした.
相対震度は, $\$ 4$ の点震源による方法で誤差が小さ かった $97 / 4 / 3$ の愛媛県南予地方地震の相対震度 (Fig. 4(a))を用いる. 距離減衰式については, スラブ内地震用 の (4) 式を用いる.

震度インバージョン解析による $M_{I}$ に対する震度の評 価誤差の RMS 值を Fig. 10(a) に示す. 䛊差最小となる $M_{I}$ は $M_{J}$ と同じ 6.6 となった. Fig. 10(b) は誤差最小と なる $M_{I}=6.6$ の場合の放出エネルギー分布を示す. 全体 の放出エネルギーの $70 \%$ 以上を示す領域を実線で囲ん で示し, この領域を以後短周期地震波発生域と呼ぶ.さ らに，そのエネルギー重心を $\triangle$ で示し，以後短周期中心 と呼ぶ. 仮定した断層面の北側に短周期地震波発生域が 生じており, Fig. 5 に○で示した余震の震央分布と比べ ると, 余震が発生していない領域に対応している. 前述 したように，ほとんどのプレート境界の大地震の場合， 短周期中心はアスペリティの破壊の終端部にあった。一 方, 加藤 (2006) はプレート境界では固着域の周りで非 地震性すべりが先行し, 結果として残された部分が大地 震時にアスペリティになると考えて, 動的破壊シミュ 

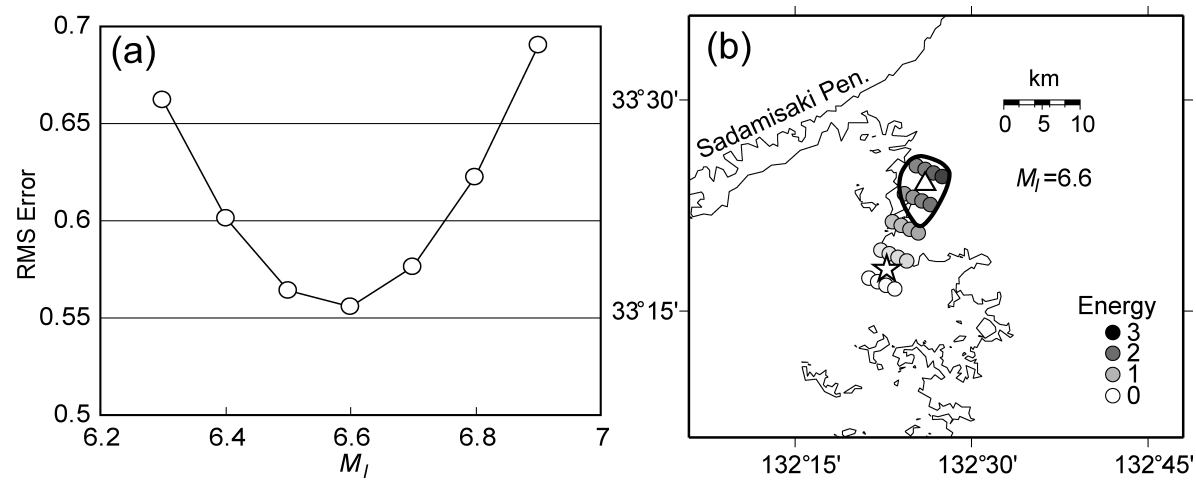

Fig. 10. Results of the intensity inversion analysis for the 1968 earthquake. (a) Root mean square errors of intensity estimation in terms of magnitude and (b) released short-period energy distribution for the case of least error. An area surrounded by a solid line shows a short-period radiation zone (SPRZ) and a triangle shows its energy centroid. A star shows the epicenter [JMA (2007)].

レーションを行い, アスペリティの終端部に破壊の先端 部が集中することで，すべり速度が増大し，短周期成分 が強く励起されるのではないかと指摘し, 震度インバー ジョンの結果と調和的であることを示した. しかし，こ こで検討対象としたスラブ内地震は, $M_{J}=6.6$ 程度の規 模なのでアスペリティのサイズは小さく, 例えプレート 境界地震と同じメカニズムを考えても, 震度インバー ジョンの解像度から判断するとアスペリティと短周期中 心はほぼ同じ場所に評価されると考えられる。したがっ て, Fig. 10(b) で示した短周期中心と震央 [気象庁 (2007)］の位置関係から判断すると，断層面上を南から 北に破壊が伝播したと考えられ，断層面の北側にアスペ リティがあると推察される.

\subsection{4 年伊予西部の地震}

1854 年伊予西部の地震について, Fig. 1(c) に示す震 度分布を用いて震度インバージョン解析を行い, 短周期 地震波発生域と地震規模を推定する.

断層モデルについては, この近傍の地域のスラブ内地 震のメカニズムを参考に仮定する. すなわち, Imagawa et al. (1985) は, この地域の M 6 クラスのスラブ内地震 は海洋プレートの沈み込む方向に垂直な走向の断層面で ある可能性が高いことを指摘している。さらに，1968 年 8 月 6 日の地震が震源深さ $40 \mathrm{~km}$ で走向 $293^{\circ}$, 傾斜 角 $70^{\circ}, 1979$ 年 7 月 13 日の地震が震源深さ $70 \mathrm{~km}$ で 走向 $109^{\circ}$, 傾斜角 $90^{\circ}, 1983$ 年 8 月 26 日の地震が震 源深さ $116 \mathrm{~km}$ で走向 $105^{\circ}$, 傾斜角 $56^{\circ}$ と評価してい る. 傾斜角は海洋プレートの応力軸方向に対して約 $45^{\circ}$ の角度とするとほぼ説明できる. 1854 年の地震は震源 深さが 1968 年の地震と 1979 年の地震の中間で, 曲げ フロントの西側でプレートの沈み込み角度が $35^{\circ}$ 程度と
考えられるので，傾斜角は $80^{\circ}$ とた．走向は，地震発 生層上面の等深度コンターに打沶む称沿う方向である $198^{\circ}$ とした.

断層長さについては, 他のスラブ内地震では $M_{J} 6.6$ の 1968 年豊後水道の地震が約 $20 \mathrm{~km}$ [Shiono and Mikumo (1975)], $M_{J} 6.7$ の 2001 年芸予地震が $30 \mathrm{~km}$ [Kakehi (2004)], $M_{J} 7.1$ の 2003 年宮城県沖の地震が約 $30 \mathrm{~km}$ [針生・他 (2003)］である. 点震源による距離減 衰式による結果では $M_{I} 7.0$ なので 1854 年の地震の断 層長さは $32 \mathrm{~km}$ とした. 断層モデルは, 最適な断層位置 を評価するために Fig. 11(a) に示すように, $32 \times 16$ $\mathrm{km}^{2}$ の長方形の面を 10 ケース仮定する. モデル10が宇 佐美 (2003)の 1854 年の地震の震央方を含んだ断層面 である. 1 辺の長さ $4 \mathrm{~km}$ の正方形の小断層 $8 \times 4$ 個に 分割する. 断層面の最浅端 (東縁) の深さは Fig. 11(a) に点線で示す地震発生層上面 [松崎・他 (2003)］とす る.

相対震度は, $\$ 4$ の点震源による方法で誤差が小さ かった Fig. 4(b) に示す豊後水道近傍の地震の平均を用 いる. 距離減衰式については，スラブ内地震用の (4) 式 を用いる。

Fig. 11(b) に全ての解析ケースのマグニチュードと誤 差の RMS 值の関係を示す。誤差最小となる地震規模に ついては, 西寄りの断層面であるモデル(1), (4), (7)は $M_{I}$ $=7.1$ で, それ以外のモデルは $M_{I}=7.0$ となった. これ は宇佐美 (2003) による 1854 年の地震の規模 $M_{U}=7.3$ 〜 7.5 と比べて小さい. 䛊差最小となるモデル(5)で $M_{I}=$ 7.0 の場合の震度インバージョン解析結果を Fig. 11(c) に示す．短周期中心は断層面の北側で大分県佐賀関半島 東方沖にある結果となった。 

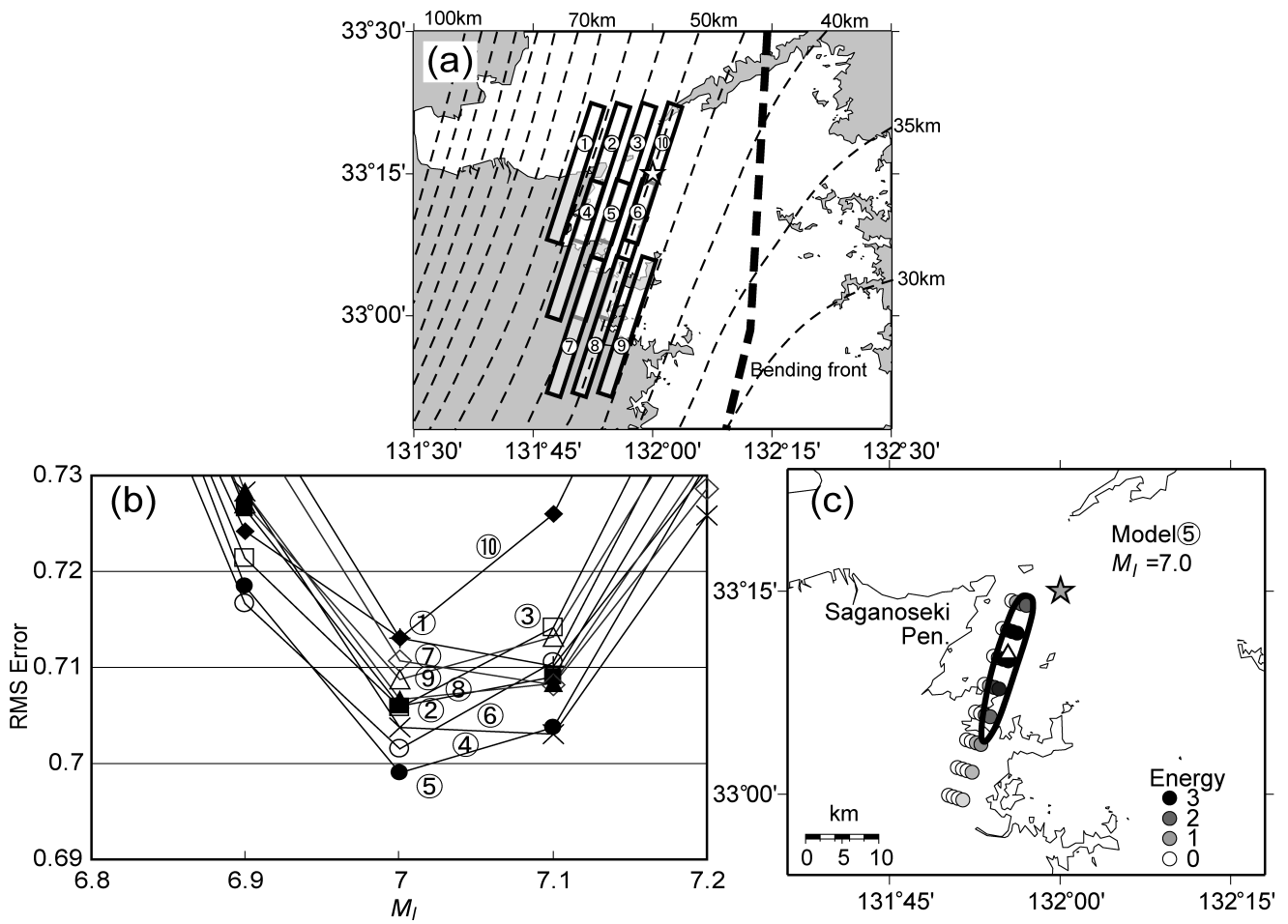

Fig. 11. Results of the intensity inversion analysis for the 1854 earthquake. (a) Fault plane models for analysis, (b) root mean square errors of intensity estimation in terms of magnitude and, (c) released short-period energy distribution for the case of least error. An area surrounded by a solid line shows a SPRZ and a triangle shows its energy centroid. A star shows the epicenter [Usami (2003)].

\subsection{9 年伊予宇和島の地震}

1968 年の地震と震度分布が似ているので 1968 年の 断層面を基準とする. Shiono and Mikumo (1975) によ る 1968 年の地震のメカニズム $\left(\mathrm{Dip}=72^{\circ}\right.$, Strike $=$ $203^{\circ}$ ) で, $20 \times 16 \mathrm{~km}^{2}$ の長方形の断層面を仮定し, 1 辺 の長さ $4 \mathrm{~km}$ の正方形の小断層 $5 \times 4$ 個に分割する.

Fig. 12(a) に示すように断層面の形状，傾き，走向が同 じ 13 ケースの断層モデルを仮定する。モデル11が 1968 年伊予西部の地震の断層モデルと同じであり, モデル13 が宇佐美 (2003)の 1749 年の地震の震央々を含んだ断 層面である. 1854 年の地震と同じように断層面の最浅 端 (東縁) の深さは Fig. 12(a) に点線で示す地震発生層 上面とする.

相対震度は, $\$ 4$ の点震源による方法で誤差が小さく 1968 年の地震にも用いた，Fig. 4(a) に示す 97/4/3の 愛媛県南予地方地震の相対震度を用いる. 距離减衰式に ついては，スラブ内地震用の (4) 式を用いる.

すべての断層モデルの解析結果の誤差と $M_{I}$ の関係を Fig. 12(b) に示す. モデル(1)を除く解析ケースで $M_{I}=$
6.7 の場合が誤差最小となり，これは宇佐美 (2003)の 1749 年の地震規模 $M_{U}=6(3 / 4)$ とほぼ同じ值となった. また， 1968 年の地震の $M_{I}=6.6$ とほぼ同規模である. 誤差最小となるモデル (6)で $M_{I}=6.7$ の場合の震度イン バージョン解析結果を Fig. 12(c) に示す。短周期中心に ついては，佐田岬半島の付根付近でスラブ内地震の発生 頻度が一番高い領域 [松崎・他 (2003)］にある。また,

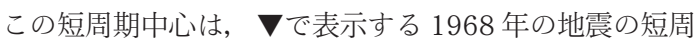
期中心と約 $13 \mathrm{~km}$ の距離しかなく, 震源位置は 1968 年の地震と似通った地震と考えられる.

\subsection{6 年慶長豊後地震}

別府湾一日出生断層帯東部の断層で発生したとして断 層面をモデル化する. 別府湾一日出生断層帯東部の断層 は複数存在する [島崎・他 (2000)］ので Fig. 13(a) に示 すように四つの断層モデルを仮定する．点震源による最 適 $M_{I}$ が 7.2 なので $M_{J}=7.2$ とすると, 武村 (1998)によ ると断層長さは $22 \mathrm{~km}$, 深さ方向幅 $13 \mathrm{~km}$, さらに松田 (1975) によると断層長さは $26 \mathrm{~km}$ となる. 断層長さに ついては, 別府湾内で最も活動的な別府湾中央断層は 

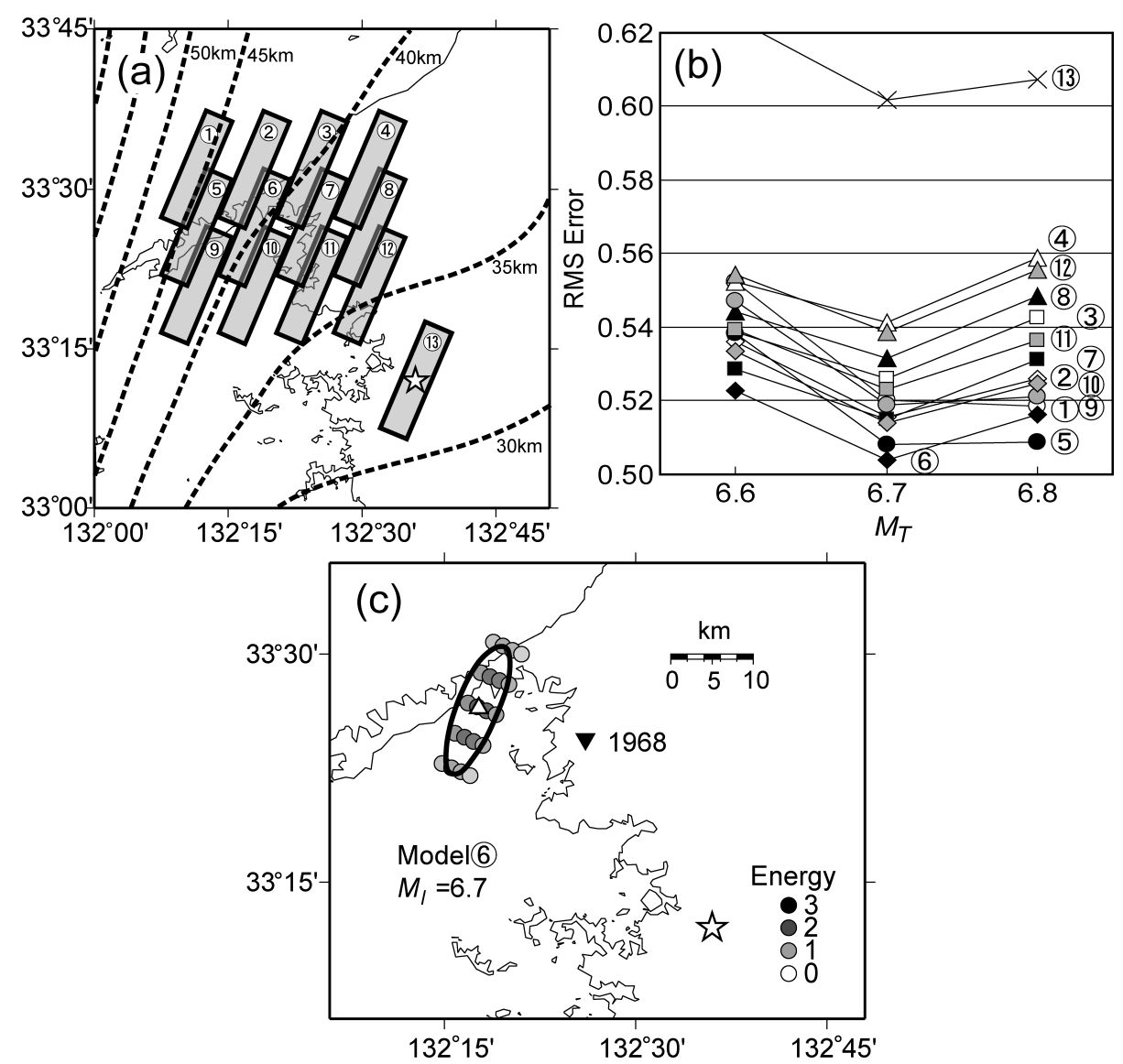

Fig. 12. Results of the intensity inversion analysis for the 1749 earthquake. (a) Fault plane models for analysis, (b) root mean square errors of intensity estimation in terms of magnitude, and (c) released short-period energy distribution for the case of least error. An area surrounded by a solid line shows a SPRZ and a triangle shows its energy centroid. A star shows the epicenter [Usami (2003)].

$22 \mathrm{~km}$ 以上あること [島崎・他 (2000)], 津波の波源域 の解析 [石辺・島崎 (2005)］によれば別府湾内によどま らずさらに東域に延びていたことなどを考慮して 26 $\mathrm{km}$ とした。断層面はほぼ鉛直と考えられる「地震調査 研究推進本部 (2005)］ので, 傾斜角は $90^{\circ}$ と仮定する. 断層面の深さは 3 $16 \mathrm{~km}$ とする. 断層面は, 1 辺の長 さは約 $3 \mathrm{~km}$ の $9 \times 4$ 個の長方形の小断層に分割する. 相対震度は, Fig. 8 に示す 1975 年大分県中部地震のも のを用いる. 距離減衰式は, 浅い地款内地震用の (5) 式 を用いる.

全ての断層モデルに対して震度インバージョン解析を 行う. $M_{I}$ に対する震度評価誤差の RMS 值を Fig. 13(b) に示す.一番大分寄りのモデル(4)で $M_{I}=7.2$ の場合が誤 差は一番小さい. 宇佐美 (2003) の地震規模 $M_{U}=7.0$ に 比べて若干大きくなった. この誤差最小の場合の放出工
ネルギー分布を Fig. 13(c) に示す. 断層のほぼ中央で被 害の大きかった大分市の近傍に短周期中心があることが わかる。

震度インバージョン解析によって求めた最適な $M_{I}$ と その誤差を Table 2 にまとめて示す. 点震源を仮定し距 離減衰式による方法で評価した $M_{I}$ と比較すると, 1749 年の地震が 0.1 大きくなっただけでほぼ同じ結果となっ た. 断層の仮定によって誤差が最小となる地震規模 $M_{I}$ はほとんど変わらないことがわかった。 スラブ内の歴史 地震について従来の宇佐美 (2003) の地震規模と比べる と, 1749 年の地震は $M_{I}=6.6 \sim 6.7$ となりほとんど変わ らず, 1854 年の地震は $M_{I}=7.0$ となり, 0.4 小さくなっ た.これは, 1749 年の地震は 1968 年の類似の地震を参 照して評価されたが, 1854 年の地震は類似の地震が近 年発生してないため過大評価されていたと考えられる。 

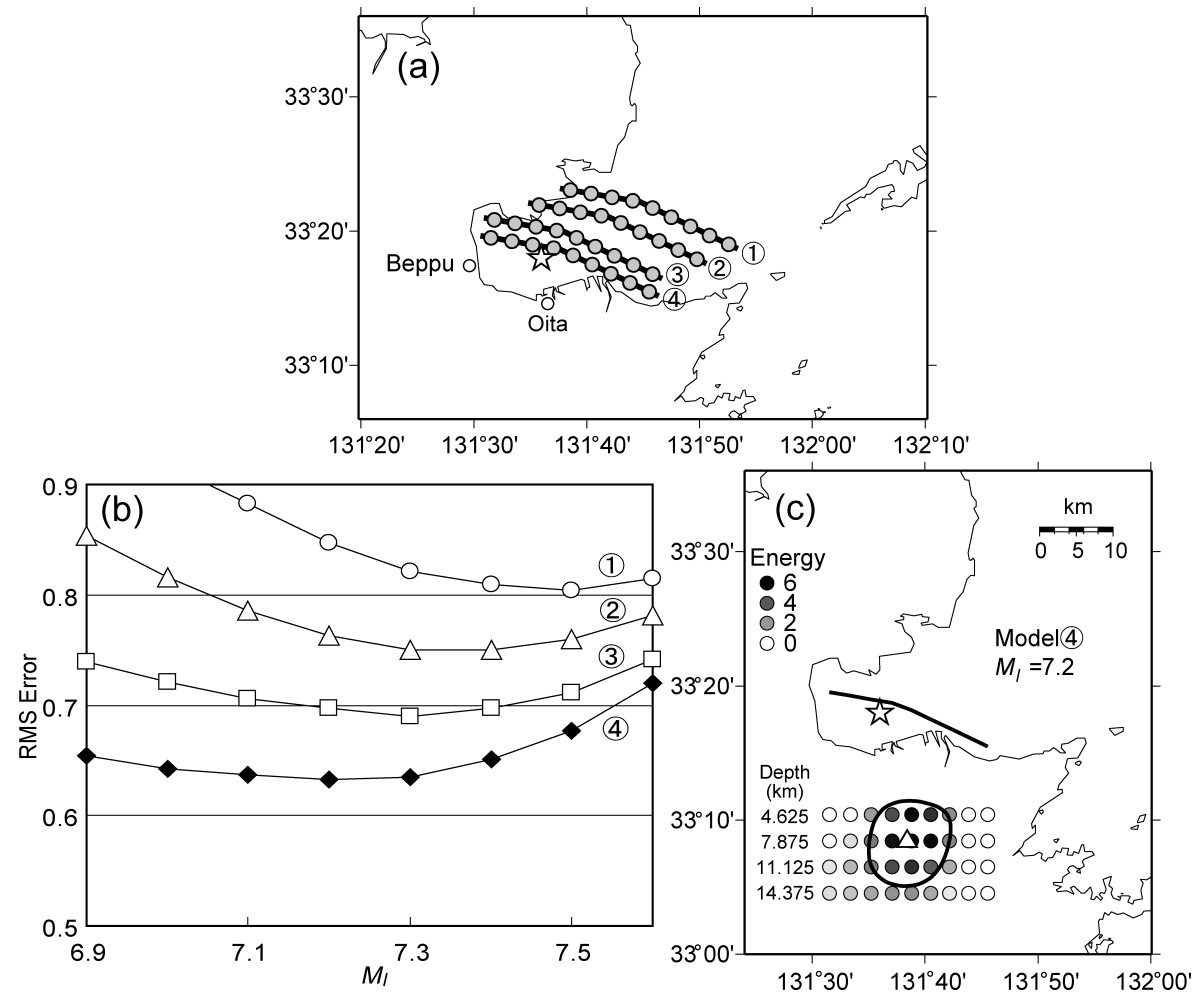

Fig. 13. Results of the intensity inversion analysis for the 1596 earthquake. (a) Fault plane models for analysis, (b) root mean square errors of intensity estimation in terms of magnitude, and (c) released short-period energy distribution for the case of least error. An area surrounded by a solid line shows a SPRZ and a triangle shows its energy centroid. A star shows the epicenter [Usami (2003)].

\section{§6. 考察}

地震規模を推定する方法として, ここまで点震源の距 離減衰式による方法と震度インバージョン解析による方 法を用いた。しかし, 従来からはある震度以上の地域の 面積から経験式で換算する方法が用いられてきた [たと えば村松 (1969), 勝又・徳永 (1971)]. ここでは，この 方法を豊後水道近傍のスラブ内地震に適用するための問 題点と修正方法について検討する. Fig. 1 に実線で囲ん で示す震度 5 以上の範囲を用いて地震規模の評価を行 う. 震度 5 の範囲は宇佐美・大和探査 (1994) に記載さ れた図を参考に設定した。評価した震度 5 の領域面積 $S_{5}\left(\mathrm{~km}^{2}\right)$ を Table 2 に示す.

震度 5 以上の地域面積 $S_{5}\left(\mathrm{~km}^{2}\right)$ からマグニチュード に換算する村松 (1969) による経験式を (6) 式に示す.

$$
\log S_{5}=M-3.2
$$

(6) 式は震源が比較的浅い地震に対して評価されている ので，短周期地震動が卓越する傾向にある比較的深いス ラブ内地震では震度 5 以上の地域面積が広くなりマグ ニチュードが過大評価されやすい. 例えば, 1968 年豊
後水道の地震の場合, Table 2 に示すように Fig. 1(d) で 実線で囲んだ震度 5 以上面積は $S_{5}=12,380 \mathrm{~km}^{2}$ で，(6) 式に代入すると $M=7.3$ となる。 また, 近傍の海域で発 生した 2001 年芸予地震 $\left(M_{J}=6.7\right.$, 深さ $\left.46 \mathrm{~km}\right)$ につい ては $S_{5}=17,690 \mathrm{~km}^{2}$ で $M=7.4$ となり [高橋・他 (2005)], どちらの地震む気象庁マグニチュードより 0.7 過大評価になってしまう。 そこで, 震度 5 以上の領域面 積から 1968 年地震は $M=6.6$ となり, 2001 年芸予地震 は $M=6.7$ と評価できるように (6) 式の定数項を修正す ると, (7) 式となる.

$$
\log S_{5}=M-2.48
$$

(7) 式は (6) 式と比べると同じ領域面積であれば地震規 模が 0.72 小さく評価されることを示している. (7) 式を 用いて 1854 年の地震を評価すると $M=7.0$ となる. 点 震源の距離減衰式による評価および震度インバージョン 解析による $M_{I}$ と同じで, (7) 式は妥当であると考えられ る.

ただし，古い地震に (7) 式を適用しようとすると別の 問題がある. 1968 年の地震と震源・地震規模がほぼ同 


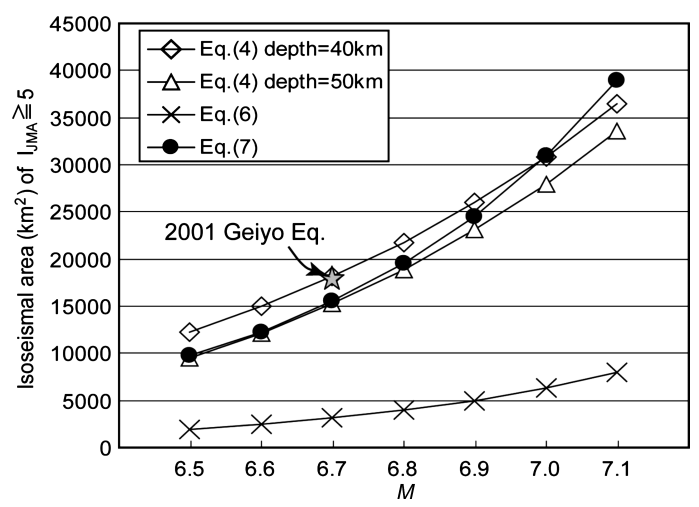

Fig. 14. Comparison of the relationship between magnitude and isoseismal area of $I_{\mathrm{JMA}} \geqq 5$. Diamonds and triangles are estimated from the attenuation relationship equation (4) neglecting relative intensity for site correction. Crosses and black circles are calculated from equations (6) and (7), respectively. A star shows an observation value of the 2001 Geiyo earthquake.

じと考えられる 1749 年の地震については, 震度 5 以上 の面積が $S_{5}=7,820 \mathrm{~km}^{2}$ で, 1968 年の地震の $63 \%$ し かなく, (7) 式を用いると $M=6.4$ となり, 震度インバー ジョンによる評価結果より 0.3 程度小さくなる。さら に, 1596 年の地震は浅い地震なので, (6) 式で妥当な評 価ができるはずであるが， $M=6.7$ でかなり小さい. こ れは, 古い時代になるほど震度データが少なく, 震度 5 以上の範囲を狭く見積もるため, 地震規模が過小評価さ れてしまうことを示している. したがって, 震度の点数 から判断して 1749 年と 1596 年の地震の震度 5 以上の 面積から推定したマグニチュードは妥当ではないと考え られるので, Table 2 には括弧で参考值として示した.

さらに, 豊後水道のスラブ内地震用の震度の距離减衰 式を用いて, 相対震度を無視した場合の震度 5 以上とな る領域の面積を求め, (7) 式を検証する. 評価方法として は, (4) 式を用いて震度 4.5 となる震源距離 $X$ を求め, 豊後水道のスラブ内地震として標準的な震源深さである $40 \mathrm{~km}$ と $50 \mathrm{~km}$ の場合の震央距離を求める. 次に, こ の震央距離を半径とする円の面積を求め, 震度 5 以上と なる領域の面積とする，マグニチュードを変えて評価 し, (6) 式および (7) 式の結果と比較して, Fig. 14 に示 す。また, Fig. 14 には 1968 年および 1854 年の地震, さらに 2001 年芸予地震のマグニチュードと震度 5 以上 の領域の面積の関係を坉印で示す。距離減衰 (4) 式から 評価した震度 5 以上の領域の面積は, Fig. 14 に示すマ
グニチュードの範囲においては (7) 式から評価した結果 とほぼ同様な結果が得られることがわかる.

最後に, 従来から用いられている震央 [宇佐美 (2003)］ と短周期中心との位置関係を考察する. 1854 年, 1749 年, 1596 年の地震については, Figs. 11〜 13 に々で宇佐美 (2003) の震央位置をそれぞれ示した.

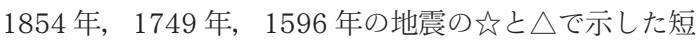
周期中心の間の距離は，それぞれ $11 \mathrm{~km}, 39 \mathrm{~km}, 4 \mathrm{~km}$ である. 1968 年の地震の震央 [気象庁 (2007)] と短周期 中心の間の距離が $12 \mathrm{~km}$ であることを考えると， 1854 年と 1596 年の地震はそれ以下の距離であり, 評価誤差 の範囲内であり，宇佐美 (2003) の震央と整合する結果 と考えられる.

しかし，1749 年の地震については, Table 2 に示す距 離減衰式による評価結果からわかるように, 震度イン バージョン解析の結果と比べると，认を震央とした場合 $M_{I}$ の評価としてはあまり変わらないが，誤差はかなり 大きい. 似通った地震である 1968 年の地震の短周期中 心マからの距離を比べると, 1749 年の地震の短周期中 心 $\triangle$ は $13 \mathrm{~km}$ で, $27 \mathrm{~km}$ 離れたえより近い.さらに, $\triangle$ はスラブ内地震の発生頻度の高い佐田岬半島付根付近 [松崎・他 (2003)］にあり, 1749 年の地震の短周期中心 付近を震央としたほうが可能性は高いと考えられる.

\section{§7. ま と め}

16 世紀末以降豊後水道近傍で発生した主な被害地震 を対象とし，震度分布を用いて，スラブ内地震について は 1968 年 8 月 6 日豊後水道の地震 $\left(M_{J} 6.6\right)$ および浅い 地殼内地震については 1975 年 4 月 21 日大分県中部地 震を基準として, 点震源による方法ならびに震度イン バージョン解析によって地震規模を決め直した. 対象と した地震は 1968 年の地震の他に, 1854 年, 1749 年お よび 1596 年の 4 地震とする。 その結果以下のような結 論を得た。

(1) 1854 年の地震は， スラブ内地震で大分県佐賀関半 島東方沖に短周期中心があり， $M=7.0$ と推定された. 従来の $M=7.4$ [宇佐美 (2003)］より規模は小さいと 評価された。この地震規模がこの地域のスラブ内の歴 史地震としては最大規模である。

(2) 1749 年の地震は, $M=6.6 \sim 6.7$ となり, 1968 年の 地震と地震規模がほぼ同じであり, 短周期中心が 1968 年の地震の震央に近い愛媛県佐田岬半島付根近 傍にあるスラブ内地震と推定された.

(3) 1596 年の地震は, 別府湾内の浅い地殼内地震と判 断し，2000 年鳥取県西部地震や 1975 年大分県中部 地震などの震度データの分析により評価したこの地域 
の浅い地震用の相対震度や距離減衰式に基づいて推定 を行った. 別府湾中央断層付近の断層と考えられ, $M$ $=7.2$ と推定された.

(4) 村松 (1969) による震度 5 以上の範囲の面積と $M$ の 経験式を用いると, 豊後水道のスラブ内地震の場合, 地震規模を 0.7 程度過大に評価する可能性があること がわかった。 これは, やや深いスラブ内地震は短周期 成分が励起されやすい特性をしているため, 経験式の 基になっている浅い地震と震度分布が異なっているこ とに起因しているものと考えられた。 そこで, 村松 (1969) による経験式を修正して安芸灘・伊予灘・豊 後水道のスラブ内地震の場合に正しく評価できる (7) 式を提案した. この式により歴史地震の規模を見直す 之, 古い地震は震度観測点が少ないため過小評価する が, 震度観測点の比較的多い 1854 年の地震は $M=$ 7.0 となり, 点震源による手法および震度インバー ジョン解析の結果と同じになった。

(5) 宇佐美 (2003) の震央と短周期中心の位置を比べる と, 1854 年と 1596 年の地震は近傍で整合する結果 となった。 1749 年の地震については, 両者が $39 \mathrm{~km}$ 屯離れた結果となったが, 短周期中心の方が, 震度分 布の類似している 1968 年の地震の震央と近くてスラ ブ内地震の発生頻度の高いフィリピン海プレートの曲 げフロントの西側の佐田岬半島付根にあり, 可能性が 高いと考えられる.

\section{謝辞}

森川信之氏および匿名の 2 名の査読者, 編集担当委員 の藤原広行氏には, 極めて有益なご意見を頂き, 本論文 の改善に非常に役立ちました，地震のメカニズム解は， 防災科学技術研究所の広帯域地震観測網のデー夕を使用 しました。 また, 図の作成にはGMTを使用しました。 ここに記して深く感謝の意を表します.

\section{文献}

Asano, K. and T. Iwata, 2006, Source process and near-source ground motions of the 2005 West Off Fukuoka Prefecture earthquake, Earth Planets Space, 58, 93-98.

Furumura, T. and B. L. N. Kennett, 2001, Variations in regional phase propagation in the area around Japan, Bull. Seism. Soc. Am., 91, 667-682.

針生義勝 - 関根秀太郎・汐見勝彦・小原一成, 2003, 防 災科研 Hi-net による 2003 年 5 月 26 日宮城県沖の地 震の余震分布, 日本地震学会講演予稿集, 2003 年度 秋季大会, A076.

Hatori, T., 1969, Dimensions and geographic distribution of tsunami sources near Japan, Bull. Earthq.
Res. Inst., 47, 185-214.

羽鳥徳太郎, 1985, 別府湾沿岸における慶長元年 (1596 年) 豊後地震の津波調査, 地震研究所彙報, 60, 429438.

羽鳥徳太郎, 1995, 日本近海における津波マグニチュー ドの特性, 日本地震学会講演予稿集, 1995 年度秋季 大会, B42.

引田智樹・工藤一嘉, 2001, 経験的グリーン関数法に基 づく 1855 年安政江戸地震の震源パラメーターと地震 動の推定, 日本建築学会構造系論文集, 546, 63-70.

池田 孝・武村雅之・加藤研一，2003, 強震記録に基づ く東北地方周辺のやや深発地震の高振動数成分の励起 特性, 日本建築学会構造系論文集, 572, 39-46.

Imagawa, K., K. Hirahara and T. Mikumo, 1985, Source mechanisms of subcrustal and upper mantle earthquakes around the northeastern Kyushu region, southwestern Japan, and their tectonic implications, J. Phys. Earth, 33, 257-277.

石辺岳男・島崎邦彦， 2005, 1596 年慶長豊後地震に伴 う津波の波源推定, 歴史地震, 20, 119-131.

地震調査研究推進本部, 2005, 別府-万年山断層帯の長 期評価について (平成 17 年 3 月 9 日公表), 73 pp.

Kakehi, Y., 2004, Analysis of the 2001 Geiyo, Japan, earthquake using high-density strong ground motion data: Detailed rapture process of a slab earthquake in a medium with a large velocity contrast, J. Geophys. Res., 109, B08306, doi: 10.1029/ 2004JB002980.

神田克久・武村雅之, 2005, 震度データから検証する宮 城県沖で発生する被害地震の繰り返し, 地震 2,58 , 177-198.

神田克久・武村雅之, 2006 , 十勝沖地震の震度インバー ジョン解析, 月刊地球, 号外 55, 64-70.

神田克久・武村雅之, 2007 , 震度デー夕から推察される 相模トラフ沿いの巨大地震の震源過程, 日本地震工学 会論文集， 7, 2 (特集号)，68-79.

神田克久・武村雅之・宇佐美龍夫, 2003, 震度データを 用いた震源断層からのエネルギー放出分布のインバー ジョン解析, 地震 $2,56,39-58$.

神田克久・武村雅之・宇佐美龍夫, 2004, 震度インバー ジョン解析による南海トラフ巨大地震の短周期地震波 発生域, 地震 $2,57,153-170$.

加藤尚之, 2006 , アスペリティ破壊の終端域での短周期 地震波発生のメカニズムについて, 日本地球惑星科学 連合 2006 年大会予稿集, S111-002.

勝又 護・徳永規一, 1971 , 震度 IV の範囲と地震の規 模抢よび震度と加速度の対応，験震時報， 36, 89-96.

気象庁, 2006 , 平成 18 年 1 月 12 月地震 - 火山月報 (防災編).

気象庁, 2007, 平成 17 年地震年報 CD-ROM, (財)気象 業務支援センター.

松田時彦, 1975, 活断層加ら発生する地震の規模と周期 について, 地震 $2,28,269-283$.

松崎伸一・大野裕記・池田倫治・福島美光, 2003, 震源 分布からみた伊予灘周辺フィリッピン海プレートの形 状执よ゙地震特性, 地震 $2,56,267-279$.

村松郁栄, 1969 , 震度分布と地震のマグニチュードとの 
関係, 岐阜大学教育学部研究報告一自然科学, 4, 169176.

中村 操・笠原慶一, 2001, 歴史地震の規模の推定, 月 刊地球, 23, 84-88.

中西一郎, 2002, 文禄五年閏七月九日（1596 年 9 月 1 日）の地震による伊予での被害を示す史料, 地震 2 , 55, 311-316.

小原一成・廣瀬 仁, 2004, 豊後水道付近のスロース リップイベントと深部低周波微動, 地震予知連絡会 報, 71, 671-679.

Ohno, S., T. Ohta, T. Ikeura, and M. Takemura, 1993, Revision of attenuation formula considering the effect of fault size to evaluate strong motion spectra in near field, Tectonophysics, 218, 69-81.

岡田篤正, 2006, 活断層で発生する大地震の連動・連 鎖一中央構造線・濃尾断層系・山陰地域の活断層を事 例として, 月刊地球, 号外 54, 5-24.

表 俊一郎, 1976, アンケート震度に基づく震度分布に 関する考察, 日本建築学会 (編)「1975 年大分県中部 地震による RC 建物の被害調査報告一九重レークサイ ドホテルおよびその周辺建物の被害—」，212-225.

鷺谷 威・西村卓也 - 畑中雄樹 - 福山英一 - W. L. Ellsworse, 2002, 2000 年鳥取県西部地震に伴う地款変動 と断層モデル, 地震 $2,54,523-534$.

島崎邦彦 - 松岡裕美 - 岡村 眞 -千田 昇 - 中田 高, 2000, 別府湾の海底活断層分布, 月刊地球, 号外 28, 79-84.
Shiono, K. and T. Mikumo, 1975, Tectonic implications of subcrustal normal faulting earthquakes in the western Shikoku region, Japan, J. Phys. Earth, $23,257-278$.

高橋利昌・浅野彰洋 - 大内泰志・神田克久 ・武村雅之・ 宇佐美龍夫，2005，四国北西部における歴史的なスラ ブ内地震の地震諸元に関する検討, 四国電力, 四国総 合研究所, 研究期報 No. 85, 37-45.

武村雅之, 1998 , 日本列島における地殼内地震のスケー リング則，地震 $2,51,211-228$.

武村雅之・神田克久, 2006, 宮城県沖で 2005 年 8 月 16 日に起こった地震 $(M=7.2)$ の震度分布の特徽と短 周期地震波発生域, 地震 $2,59,147-158$.

武村雅之・神田克久 - 水谷浩之, 2006, 1968 年十勝沖 地震と 1994 年三陸はるか沖地震の震度インバージョ ン解析結果一短周期地震波発生域とアスペリティ, 日 本地震学会講演予稿集, 2006 年度秋季大会, D01.

東京大学地震研究所, 1982 , 新収日本地震史料, 第二 巻, 575 pp.

佃 為成・三浦勝美, 2002, 2001 年芸予地震とプレー トの曲げモーメント, 地震 2, 55, 91-96.

宇佐美龍夫, 2003, 最新版日本被害地震総覧 [416]2001 , 東京大学出版会, 605 pp.

宇佐美龍夫 - 大和探查技術株式会社 (編集), 1994, わ が国の歴史地震の震度分布・等深度線図, 社団法人日 本電気協会, $647 \mathrm{pp}$. 